\title{
Arktik Bölgesi Siyaseti: Ottava Deklarasyonu'ndan Bugüne Aktör Politikaları Ve Çin'in Kutup İpek Yolu Projesi
}

\author{
DOI: 10.26466/opus.733484
}

$*$

\author{
Emre Citak * \\ * Dr. Öğr. Üyesi, Hitit Üniversitesi İktisadi ve İdari Bilimler Fakültesi, Çorum/Türkiye \\ E-Posta: emrecitak@hitit.edu.tr \\ ORCID: $\underline{0000-0002-8704-6495}$ \\ $\ddot{O} z$
}

Arktik giderek artan bir jeopolitik, jeostratejik ve jeoekonomik değerle birlikte uluslararası siyasetin gündeminde yer bulmaktadır. Küresel iklim değişikliğinin bir boyutu olan küresel ısınmanın yarattığı etki, buzullarla kaplı ve iklimi oldukça sert bu bölgede köklü değişimler yaratmaktadır. Bölgedeki buzulların erimesi çevresel bir tehdit ve ekolojik bir dönüşüm oluştururken siyasi, ekonomik, bilimsel, askeri, ticari alanlarda da ortaya çeşitli fırsatlar çıkarmaktadır. Hem bölge hem de bölge dı̨̧ı aktörler de bir yandan uluslararası güvenlik meselesi haline gelen küresel ısınmaya yönelik çalışmalar yürütmek isterken diğer taraftan ulusal çıkarları bağlamında paylaşımdan pay alma iradesi göstermektedirler. Bu kapsamda bölge giderek büyük aktörlerin politikalarının yoğunlaştığı bir odak noktası haline gelmiştir. Arktik ayrıca uluslararası alanın yükselen gücü olan Çin'in ise küresel açllımın sergilediği yerlerden biri olarak ön plana çıkmaktadır. Bölgedeki alternatif ticaret yolu güzergâhı, enerji kaynakları, değerli madenler, bilimsel keşifler, turizm gibi potansiyeller Çin'in yöneliminin temel güdülerini oluşturmaktadır. 2018 yılında açıklanan "Beyaz Kitap" ile Çin Arktik politikasının resmi ana hatlarını çizmiş ve Yol ve Kuşak Projesinin bir ayağın oluşturacak olan Kutup İpek Yolu girişimini açıklamıştır. Bu çalışmada öncelikle Arktik Bölgesinin kısa bir tanıtımına yer verilecek, ardından Ottava Deklarasyonu uyarınca 1996 yılında bölgedeki 8 devlet ve yerel halkların üyelerini oluşturduğu Arktik Konseyi'ne değinilecektir. Arkasından da Arktik'teki aktörlerin politikalarının genel hatları ele alınacak ve bir bölge dışı aktör olan Çin'in Arktik siyaseti, Kutup İpek Yolu projesi üzerinden incelenecektir.

Anahtar Kelimeler: Arktik, Arktik Konseyi, Çin, Kutup İpek Yolu 


\title{
Arctic Region Politics: Actor Policies From Ottawa Declaration To Today And China's Polar Silk Road Project
}

\begin{abstract}
The Arctic is on the agenda of international politics, with an increasing geopolitical, geostrategic and geoeconomic value. The impact of global warming, which is a dimension of global climate change, has created a radical change on the region which is covered with glaciers and has a very harsh climate. While the melting of glaciers in the region creates an environmental threat and an ecological transformation, it presents various opportunities in political, economic, scientific, military and commercial fields. Both regional and non-regional actors, on the one hand, want to carry out studies on global warming, which have become an international security issue, on the other hand, they show the will to get share from the context of their national interests. In this sense, Arctic has gradually become a focal point in which the policies of great actors are concentrated. The Arctic also stands out as one of the places where China, the rising power of the international area, exhibits its global expansion. Potentials such as alternative trade route, energy resources, valuable metals, scientific discoveries, tourism in the region are the main lines of China's orientation. With the "White Book" announced in 2018, China laid out the official outline of the Chinese Arctic policy and explained the idea of the Polar Silk Road, which will form one leg of the Belt and Road Initiative. In this study, first of all, a brief introduction to the Arctic Region will be given, and then the Arctic Council, which was formed according to Ottawa Declaration by 8 states and local people in the region, will be included. Then, the general outlines of the policies of the actors in the Arctic will be discussed and as an outer actor China's Arctic policy will be examined through the Polar Silk Road project.
\end{abstract}

Keywords: Arctic, Arctic Council, China, Polar Silk Road 


\section{Giriş}

Antarktik'in güneyini oluşturduğu kutup bölgelerinin, kuzeyini ise Arktik oluşturmaktadır. İnsanlık tarihinin büyük kısmında iklim koşulları ve ulaşım sorunları gereği genel insan yaşamına ve ekonomik faaliyetlerine uygun olmadığı düşünülen kutup bölgelerine, giderek artan şekilde uluslararası ilgi söz konusu olmaktadır. Şüphesiz bu yönelimin arkasında küresel iklim değişikliğin bir çıktısı olan söz konusu bölgelerdeki buzulların erime etkisinin olduğunu özellikle belirtmek gerekmektedir. Antarktik ile ilgili uluslararası kamuoyunda genel bir tanınırlık olmasına rağmen Arktik nispeten yeni bir meseleyi oluşturmaktadır. Arktik, kalın buz tabakalarının ortadan kalkmaya başlamasıyla birlikte bölgedeki hem deniz hem de donmuş haldeki kara alanının açığa çıkmasıyla birlikte gözlerin çevrildiği bir nokta haline gelmiştir.

Esasında Arktik bölgesi, yüzyıllardır insan yaşamını barındıran ve aynı zamanda kömür işletmesi ve balıkçılık gibi çeşitli ticari amaçlara hizmet eden bir yapıda olmuştur. Fakat bölgedeki insan varlığı bu özel çevrede yaşamaya uyum sağlayabilen az sayıdaki yerel toplulukla sınırlı kalmış ve ekonomik kârlılığın düşük kalması nedeniyle de yoğun yatırım yapılan bir alan olmamıştır. Fakat küresel bir felaket olarak görülen küresel iklim değişikliğinin oluşturduğu etkiler neticesinde Arktik için çevre başta olmak üzere bilimsel araştırmalar ve keşifler, canlı ve cansız kaynaklardan ekonomik gelir, askeri deneme ve tatbikat, ticaret güzergâhları, turizm olanakları gibi firsatlar gündeme gelmiştir. Böylece de Arktik Bölgesi kısa sürede paylaşım ve egemenlik konusunun tartışıldığı politik bir mesele olarak kendini göstermiştir. Bu mesele çok taraflı ve çok boyutlu bir nitelik göstermektedir.

Arktik Okyanusu'na sınırı olan ve Arktik Beşlisi olarak anılan devletler Amerika Birleşik Devletleri (ABD), Rusya Federasyonu (RF), Kanada, Norveç ve Danimarka'dır. Bu devletlerin yanı sıra İsveç, İzlanda ve Finlandiya'nın topraklarının bir kısmı Arktik Bölgesi'nde bulunmaktadır. Söz konusu sekiz devlet Arktik Konseyi'nin (AK) de üyelerini oluşturmaktadır. Bölgedeki hareketliliğe ve paylaşıma kayıtsız kalmak istemeyen Çin, Güney Kore, Singapur gibi Asyalı ve Almanya, Fransa, İngiltere gibi Avrupalı devletler de bölgeyle yakından ilgilenmektedir. Arktik uluslararası kamuoyunda politik, ekonomik, askeri, kültürel, toplum, çevre gibi farklı yönleriyle yeni bir sıcak noktayı oluştururken gündeme gelen en önemli sorun ise bölgedeki paylaşım üzerinden gerçekleşen aktör davranışlarıdır. Hem bölge devletleri hem de 
bölge dışı devletler Arktik'teki paylaşımdan olabildiğince karlı çıkmak istemektedirler. Bu tür bir yaklaşım da hiç şüphesiz Arktik'te kimi çatışmaları ve zorunlu işbirliği girişimlerini de kaçınılmaz kılacaktır. Örneğin; uluslararası kamuoyunun en çok dikkatini ve kıyıdaş devletlerin en çok tepkisini çeken girişimi; Arktik'i kendi anakarasının bir uzantısı olarak gören Rusya'nın 2007 yılında 4200 metre derine inerek Arktik Okyanusu'nun tabanına bayrak dikmesi oluşturmuştur. Bu olaydan sonra bölgenin statüsü üzerine olan tartışmalar daha yüksek perdeden yapılmaya başlanmıştır.

Arktik'in günümüzdeki durumu çevresel bir tehdit barındırdığı için ulusaşırı bir sorun olarak görülmektedir. Bölgede yaşanan çevresel değişimin, olası bir zorunlu göç hareketinin veya paylaşımdan doğabilecek çatışmanın küresel boyutta etkilerinin olacağı beklenmektedir. Ayrıca bölgedeki enerji kaynakları potansiyeli, alternatif bir deniz güzergâhının ortaya çıkması ve bilimsel araştırmalar için yeni koşulların oluşması uluslararası ilginin yönelmesine neden olmaktadır. Bu bağlamda Arktik'in bir değer olarak kimliklenmesi ve jeostratetik, jeopolitik, jeoekonomik öneminin giderek daha çok ön plana çıkma süreci yaşanmaktadır.

Arktik'e yönelik en yoğun ve ciddi politika yürüten devletlerden biri Çin'dir. Bölge dışı bir aktör olarak Arktik'te politikaların içerisinde barışçıl bir eğilimle var olmak istemektedir. Çin'in bu bağlamdaki resmi söylemi, bölge devletleri ile ortak amaçlarının olduğu ve dünyanın geri kalanıyla Arktik'in geleceğini beraber inşa etme üzerinden oluşmaktadır. Arktik'teki siyasi, ekonomik, bilimsel ve askeri boyutlardaki potansiyeli yakinen keşfetmesiyle birlikte Çin Kuzey Kutup Dairesi'ne yakın komşu olma konumunu israrla belirterek bölge politikalarının içerisinde gerek ikili ilişkileriyle gerek Arktik Konseyi'nde elde ettiği gözlemci statüsü üzerinden etkin olma amacı gütmektedir. Özellikle Soğuk Savaş sonrası dönemden itibaren Arktik'e çok yönlü bir yönelim gerçekleştiren Çin, 2018 yılında "Beyaz Kitap" belgesini açıklayarak resmi politikasının da ana hatlarını duyurmuştur. Çin Arktik için ekonomi, diplomasi, teknoloji, bilim ve ticari alanlardaki gücünü ve tecrübesini sunabileceğini ifade ederken ulusal çıkar arayışını da gizlememektedir. Çin 2013 yılında uluslararası kamuoyu ile paylaştığı Yol ve Kuşak Projesinin bir parçası olabilecek Kutup İpek Yolu ise; Arktik bölgesinin küresel ticaret güzergâhına eklenmesi üzerine kuruludur. Asya ile Avrupa ve Kuzey Amerika arasında ulaşımı mesafe ve maliyet olarak kısaltacak olan söz konusu proje, Rusya başta olmak üzere uluslararası alandan da destek görürken, bir 
yandan da çevre endişeleri ve Çin'in nüfuz artırma girişimi olarak algılandığı için karşıtlık oluşturmaktadır.

Bu çalışmada temel olarak, Arktik Bölgesindeki aktör politikaların genel çerçevesinin çizilmesi planlanmaktadır. Bu bağlamda özellikle Arktik Konseyi'nin yapısının incelenmesi önem arz etmektedir. Bir politika yönelimi örneği olarak da bölge dişı bir aktör olan Çin'in Arktik siyaseti ve Kutup İpek Yolu projesi incelenecektir. Çalışmanın birinci bölümünde Arktik Bölgesi ile ilgili genel bilgilere yer verilip ardından 1996 yılında Ottava Deklarasyonu ile oluşturulan AK'nin yapısına değinilecektir. İkinci bölümde ise aktörlerin Arktik'teki davranışlarının esasları konu edinilecek ve Çin'in Arktik politikasının ana hatları çizilecektir. Çalışmanın ülkemizde çoğunlukla hukuki statü üzerinden çalışılan Arktik Bölgesine farklı bir çerçevede bakması, aktör politikalarının genel çerçevesini çizmesi ve Çin'in özellikle Kutup İpek Yolu projesi üzerinden bölgeye olan yönelimini ortaya koyması açısından alana katkı sağlayacağı düşünülmektedir.

\section{Arktik Bölgesi ve Ottava Deklarasyonu}

\section{Arktik Bölgesi}

Türk Dil Kurumu'na (TDK, 2020) göre Arktik “Kuzey Kutbu’yla ilgili, Kuzey Kutbu yakınında olan" anlamına gelmektedir. Güney Kutup Bölgesi için kullanılan Antarktik terimi üzerinden de anlaşılabilecek bir kavramdır. Bölgenin sınırlarının nereden başlayıp nerede bittiğiyle ilgili genel kabul görmüş bir görüş bulunmamaktadır. Nuttall'ın editörlüğünü yaptığ1 Arktik Sözlüğü'nün (2004, s.117-118) ilgili bölümünde, Arktik'in coğrafi olarak Kuzey Buz Denizi, birçok ada ve takımada ile Kuzey Amerika, Asya ve Avrupa k1talarının anakaralarının kuzey kısımlarını içerdiği ifade edilmektedir. En büyük Kuzey Kutbu alanları Rusya, Kanada, Grönland, Alaska, Fennoscandia ve Svalbard'dadır. Her ne kadar böyle bir çerçeve çizilse de çevresel, siyasi, kültürel, coğrafi ve bilimsel yaklaşımlar bu konuda bir tartışma yaratmaktadır. Yer kürenin en kuzeyi ifade eden Arktik, Kuzey Kutup Dairesi, Arktik Okyanusu ve çevre kara ve denizlerden ibaret olup yeryüzünün yaklaşık \% 8'ini oluşturmaktadır (Spohr v.d., 2013, s.11). Genel bir ifadeyle de Arktik $66^{\circ} 33^{\prime} 39^{\prime \prime}$ enleminin geçtiği Kuzey Kutup Dairesi'nin kuzeyinde kalan bölge olarak ifade edilmektedir. 
Bölgenin özgü iklim, yer şekil ve biyolojik özellikleri bulunmaktadır. İklim, bölgeye kimliğini veren en önemli etmen olarak belirmektedir. Geniş bir alanı oluşturan Arktik'te sıcaklık değerleri yerden yere değişmektedir. Yazları bile en fazla ortalama 10 derecenin altında seyreden hava durumu, kışları konuma -50 dereceye varabilmektedir (Nutall, 2004, s. 359-360). Oldukça sert iklim ve elverişsiz yer şekilleri nedeniyle bölgede yerleşim ve nüfus yoğunluğu oldukça düşüktür. Arktik ulaşım, hareketlilik, ekonomik değer elde etme ve yaşam idame etme için dünyanın en zor bölgelerinden birini oluşturmaktadır.

Tüm dünyayı etkileyen küresel iklim değişikliğinin söz konusu bölge üzerinde etkileri daha net şekilde gözlenmektedir. Küresel ısınma buzulların erimesine neden olurken yerel halkın ve diğer canlıların hem hayatlarına yönelik tehlike oluşturmakta hem yaşam düzenlerini değiştirmeye zorlamaktadır. Deniz seviyesinin yükselmesi, buzulların çözülmesi, yerli halkın yer değiştirmek zorunda kalması (Huettmann ve Schmid, 2014, s.189-193) ve çözülen donmuş toprağın içerisinde var olan zarar gazların açığa çıkması (Taterka, 2014, s.187) gibi gelişmeler bu sürecin getirdiği olumsuz durumlardır. Hava sıcaklığı, donmuş toprak ve karbon döngüsü, hidroklimatolojideki değişim, tundra yeşilliği ve toprak ekosistemi, kar seviyesindeki düşüş, yanginlar gibi çeşitli göstergeler üzerinden Arktik'teki iklim değişikliği gözlemlenmektedir (Box v.d., 2019, s.6-12). Küresel 1sınmanın artması ile bölgede oluşan ve oluşması muhtemel gelişmeler çevresel bir endişe yaratmakla beraber, devletler dünyasında konunun esasını bölgedeki hakimiyet ve ekonomik çkar oluşturmaktadir.

İniut, Yupik ve Sami gibi yerel halkların yüzyıllardır yerleşim yeri olan Arktik Bölgesi, süreç içerisinde diş aktörlerin bir şekilde erişimine sahne olsa da uluslararası politikanın odak noktalarından biri haline gelmesi yeni bir gelişmedir. Küreselleşen dünyanın getirdiği sistem içerisinde Arktik de; doğal kaynakların, diğer hammaddelerin, ürünlerin, teknolojinin, bilginin, göçmenlerin, turistler, bilim ve iş insanlarının, sermayenin ve kültürel değerlerin serbest dolaşımının bir parçası haline gelme durumundadır. Buradaki petrol, doğalgaz ve balık gibi doğal kaynaklardan faydalanma imkanı, bölgenin bir turizm noktası olma potansiyeli, silah denemeleri gibi askeri amaçlar çerçevesinde yaralanma, özelikle buzulların erimesi üzerinden çevresel araştırmalardaki yoğunlaşma, bilimsel gözlemler gibi nedenler bölgedeki aktör yoğun- 
laşmasına, uluslararası örgütlerin girişimlerinin artmasına ve işbirliği-rekabet bağlamında uluslararası politikaların oluşmasına sebep olmaktadır (Heininen, 2005, s. 95-97). NASA (2020) verilerine göre Arktik Bölgesindeki buzul kütle 1980 yılında 7.67 milyon $\mathrm{km}^{2}$ iken on yıllık periyodlar halinde yaklaşık \%12'lik düşüşlerle 2019 yılında 4.3. milyon $\mathrm{km}^{2}$ seviyesine inmiştir. Artic Monitoring and Assessment Program (AMAP) tarafindan hazırlanan raporda (2019:4), Arktik Bölgesi'nin dünya geneline göre iki kat daha fazla ısındığı, 2014-2018 yılları arasındaki yüzey sıcaklığının 1990'den beri ölçülen en yüksek ve deniz buzu seviyesinin ise en düşük düzeyde olduğu bilgileri yer almaktadır. Arktik'te iklim değişikliği deniz seviyesi yükselmesi ve atmosfer dolaşımı yönleriyle bölge dışında yaşayan insanları da etkilemektedir. Okyanus seviyesi ve tuzluluğundaki değişim, açığa çıkacağı tahmin edilen karbondioksit ve metan gaz oranı, kuzey güney sıcak su akışı gibi alanlardaki değişimlerle birlikte Arktik ulusaşırı bir konu haline gelmektedir (Overland v.d., 2019, s. 9-11).

Bölgedeki yeraltı zenginlikleriyle ilgili en önemli araştırma 2008 yılında ABD Jeolojik Araştırmalar Merkezi (US Geological Survey) tarafından ortaya konulan veriler üzerinden oluşmaktadır. Araştırmaya göre Arktik Bölgesindeki keşfedilmemiş yaklaşık 90 milyar varil petrol, 47 trilyon $\mathrm{m}^{3}$ doğalgaz ve 44 milyar varil doğal gaz sıvıları belirlenmiştir (USGS, 2008). Bu veri; dünyadaki kanıtlanmamış doğalgaz rezervinin $\% 30$ 'u, petrolün ise \%13'ü anlamına gelmiştir (Gautier, 2009, s.1175-1176). Petrol ve doğalgazın yanı sıra altın, bakır, demir, kurşun, kalay, nikel, elmas gibi madenler de bölgenin yeraltı zenginliklerini oluşturmaktadır (Cohen, 2011, s.4). Ayrıca alternatif bir ticaret rotası haline gelecek olan bölge Avrupa-Doğu Asya güzergahın 21.000 kilometreden yaklaşık 13.000 kilometreye düşürecektir. Yine Kuzeybatı Geçidinin kullanılmasıyla birlikte Kuzey Amerika'nın batısı ile Avrupa arasındaki mesafe Panama Kanalı'na oranla 7000 km kısalacaktır. Bekkers, Francois ve Rojas-Romagosa (2015, s. 10-11) verdikleri verilerde Japonya, Çin, Güney Kore ve Tayvan gibi ülkelerden Avrupa limanlarına Arktik üzerinden deniz yolunun $\% 17$ ile $\% 40$ arasında değişen oranlarda azalacağını göstermektedirler. Panama ve Süveyş Kanalı vasıtasıyla olan geleneksel güzergâhlara ticaret rotasının başlangıç ve bitiş noktalarına göre kuzey rotalarının kullanılması mümkün hale gelebilecektir. Şüphesiz ki deniz ticaretini zaman ve maliyet yönünden daha faydalı hale getirecek alternatif güzergâhlar her iki uçta bu- 
lunan devletler tarafından ilgiyle karşılanmaktadır. Söz konusu kuzey yollarının buzulların rahat geçişe izin vereceği ölçüde ihracat ve ithalat bağlamındaki dünya ticaretinin yoğunlaşabileceği rotalardan olması kaçınılmaz hale gelebilecektir (Blunden, 2012).

\section{Ottava Deklarasyonu ve Arktik Konseyi}

Arktik Bölgesi çok uzun zamandır yerel halk dışındaki dünya için de bilinir bir konumdaydı; fakat ulaşılması ve yaşanması zorlayıcı olan böylesi bir coğrafya ilgi odağına gelmemiştir. Fakat hem Soğuk Savaş süreci ve hem de sonrasındaki dönemde egemenliğe yönelik çeşitli girişimler bölgede paylaşım sorununu da gündeme getirmiştir. Ottava Deklarasyonu ve neticesinde oluşturulan Arktik Konseyi, anlaşmaların ve teamülün yetersiz olduğu Arktik Bölgesinde bir çözüm ve uzlaşı platformu olarak ortaya çıkmıştır (Güçlü Akpınar, 2017, s.89). 1991 yılında kabul edilen çok taraflı ve bağlayıcılı̆̆ı olmayan Arktik Çevre Koruma Stratejisi'nin oluşturduğu zemin bir süre sonra Arktik Konseyi'nin oluşmasını sağlamıştır. Konsey'i oluşturacak iki temel ayak olan çevrenin korunması ve sürdürülebilir kalkınmanın, birincisi bu strateji ile işe koşulmuştur (Bloom, 1999, s.712-713).

Söz konusu 1996 tarihli Deklarasyon, Arktik Devletleri olarak kendilerini tanımlayan Amerika Birleşik Devletleri, Danimarka, Finlandiya, İzlanda, Kanada, Norveç ve Rusya Federasyonu arasında Arktik Konseyi'nin oluştuğunun beyanı niteliğindedir (Arktik Konseyi, 1996). Deklarasyon ile Arktik devletleri bölge sakinlerinin ve yerel halkının refahını ve haklarını savunacaklarını, bölgedeki sosyal, ekonomik, kültürel gelişimi ve sürdürülebilir kalkınmayı sağlayacaklarını, çevreyi ve biyoçeşitliliği koruyacaklarını, doğal kaynakları koruyacaklarını ve sürdürülebilir şekilde kullanacaklarını, bölgeyle ilgili sorunlarda işbirliği yürüteceklerini ve yerel halkı bu süreçlere dâhil edeceklerini taahhüt altına almışlardır. Ayrıca Deklarasyon ile "The Inuit Circumpolar Conference", "The Saami Council and the Association of Indigenous Minorities of the North", "Siberia and the Far East of the Russian Federation" gibi gruplara da Konsey'de kalıcı katılımcılık verilmiştir. Arktik bölgesinden olmayan devletlere ve uluslararası örgütlere de gözlemci üye olma şansı tanımıştır. Bu Deklarasyonla birlikte Konsey, askeri konuların dışarıda bırakıldığı üst düzey bir forum olarak bölgedeki diğer faaliyetlerin gerçekleştirilmesi temelinde faaliyetlerine başlamıştır. 
Günümüzde Arktik Konseyi'nin resmi ağ sayfasındaki bilgilere göre söz konusu 8 devletin yanı sira, "Aleut International Association", "Arctic Athabaskan Council", "Gwich'in Council International", "Inuit Circumpolar Council", "Russian Association of Indigenous Peoples of The North", "Saami Council" devamlı katılımc yerel nüfus temsilcileri olarak görünmektedir ve 13 devlet, 13 devletler arası uluslararası örgüt ve 12 devlet dışı uluslararası örgüt olmak üzere kalabalık bir gözlemci grubu mevcuttur (Arktik Konseyi, 2020). 1998'de Almanya, Hollanda, Polonya ve Birleşik Krallık, 2000'de Fransa, 2006'da İspanya, 2013'te İtalya, Japonya, Çin, Singapur, Kore ve Hindistan, 2017' de ise İsviçre Konsey'de gözlemci devlet statüsü elde etmişlerdir. Bu devletler Arktik Devletleri'nin hak, yetki ve sorumlulukların tanırken bölgedeki faaliyetlerin içeresinde de yer alma iradelerini belli etmişlerdir.

Arktik Konseyi bünyesinde "Arctic Contaminants Action Program, Arctic Monitoring and Assessment Programme", "Conservation of Arctic Flora and Fauna", "Emergency Prevention, Preparedness and Response", "Protection of the Arctic Marine Environment", "Sustainable Development Working Group" isimli altı çalışma gurubu bulunmaktadır. Bu çalışma grupları Arktik Konsey Bakanları tarafından alınan kararlar doğrultusunda Konsey'in çalışmalarını ve etkinliklerini yürütmektedir. Gruplar kuruluş amaçlarına göre iklim değişikliğinden bölgedeki flora ve faunanın korunmasına kadar çeşitli alanlarda faaliyet sürdürmektedir.

Arktik Konseyi; bölgede toprak sahibi olan devletlerin yanı sıra bölge dışı aktörleri, yerel halkları, devletlerarası, parlementolar arası ve devlet dışı örgütleri/kuruluşları bir araya getiren bir yapıda olduğu için bir bütünleşme ve yönetim düzlemi oluşturmaktadır. Arktik Okyanusu'na kıyısı olan beş devlet başta olmak üzere sekizli yapı her ne kadar bölgedeki egemenlik hakları ve fiziksel varlıkları nedeniyle ön planda da olsalar bölgedeki çevresel durumdan siyasi çatışmalara kadar geniş yelpazedeki gelişme hem yerel insanları hem de bölge dışı devletleri doğrudan veya dolaylı şekilde etkilemektedir. Bu durumda Arktik'te yönetişim konusunu gündeme getirmekte ve Arktik Konseyi de bu gündemin karşılığını oluşturmaktadır (Ingimundarson, 2014, s.183-184). 2011 yılında düzenlenen 7. Bakanlar Arası Toplantının ardından Konsey, Nuuk Deklarasyonu'nu ilan etmiştir. Bu toplantının ve deklarasyonun özelliği, bir yüksek seviyede forum niteliğinde olan Arktik Konseyi'nde somut adımlarının atıldığı bir gelişme olmasıdır. İmzalanan Arama ve Kurtarma Anlaşması bağlayıcılığı olan ilk metin olarak 
ön plana çıkarken Deklarsyon ile Konsey'in güçlendirilmesi, hızla değişen iklim koşullarına karşı çalışmaların yapılması, kalıcı bir Sekreterliğin kurulması ve deniz alanlarının kirlenmesine karşı acil önlemlerin işe koşulması gibi kararlar alınmıştır (Arktik Konseyi, 2011). Nuuk Deklarasyonunu, diş aktörlerin bölgede etkili olma çabasına bir cevap ve kıstas düzenleyici şeklinde de ele alınabilmektedir. Özellikle Finlandiya, Kanda ve Norveç'in bölge için çoklu ilişkiler kurma iradelerini ifade etmeleriyle beraber yeni gözlemci kabulünün önünü açmıştır (Graczyk ve Koivurova, 2014, s. 226-227). Arktik Konseyi'nin kuruluşundan bugüne kadar ne kadar etkili olduğu ve yeterliliği sorgulanabilmektedir. Çevresel sorunların, kaynak arayışlarının, paylaşım çekişmelerinin ve dış aktörlerini varlığının artması karşısında Konsey'in işlevi merak konusu olmaktadır. Arktik Konseyi'nin etkililiği üzerine 2012 yılında ortaya konulan bir araştırma makalesinin sonuç bölümünde Konsey'in bölge için bir fark yarattığı, etkili bir yapı haline geldiği, özellikle de bilgi üretimi, sorun alanlarının öne çıkarılması ve gündem oluşturulması gibi konularda yararlı olduğu vurgulanmıştır. Diğer yönden de araştırmada bölgesel ve uluslararası gelişmelere göre Konsey'in kendini yenileyebilmesi ve mekanizmalarını geliştirebilmesinin gelecekteki rolünü ve etkililiğin belirleyeceği ifade edilmektedir (Kankaanpaa ve Young, 2012, s.13).

Ottava Deklarasyonu ve Arktik Konseyi'ne değinmişken bölgede var olan diğer işbirliği yapılarını da anmak yararlı olacaktır. 1999'da oluşturulduktan sonra 2006 yılında yenilenen Avrupa Birliği, Rusya Federasyonu, Norveç ve İzlanda arasındaki Kuzey Boyutu (Nothern Dimension-ND); üyelerinin topraklarının oluşturduğu bölgede çevre, nükleer güvenlik, sağlık, enerji, ulaşım, lojistik, ticaret ve yatırım, araştırma, eğitim ve kültür gibi pek çok alanda sürdürülebilirliği ve sürekli gelişimi amaçlamaktadır (ND, 2020). Diğer bir oluşum olan Barents Avrupa Kutup İşbirliği (Barents Euro-Arctic Cooperation) ise sürdürülebilir kalkınma için 1993 yılında devletler arası düzeyde Barents Avrupa Kutup Konseyi (Barents Euro-Arctic Council) ve bölgeler arası düzeyde Barents Bölge Konseyi (Barents Regional Council) olmak üzere iki temelde kurulmuştur. Birincisinin üyeleri Danimarka, Finlandiya, İsveç, İzlanda, Norveç, Rusya ve Avrupa Komisyonu iken, ikincisinin üyeleri Finlandiya, İsveç, Norveç ve Rusya'daki 13 devlet-altı gruptan oluşmaktadır. Bu işbirliği çatısı altında üyeler ekonomi, kültür, çevre ve toplumsal refah gibi konularda politikalar geliştirmektedirler (BEAC, 2020). 
Çevre dengesinin hızla değişmesi ve bölgeye yönelik yoğunlaşan ilgi Arktik Konseyi'nin de iş yükünü artırmaktadır. Fakat hâlihazırdaki statü Konsey üyelerinin her konuda ortak karar almaları veya alınan kararların bağlayıcı nitelik göstermesi durumunu oluşturmamaktadır. Bölgedeki çok boyutlu politikalar arttıkça Konsey'in kendini yapılandırması veya sembolik bir uzlaşı forumu olarak varlığın devam ettirmesi ve bu bağlamda da Arktik'te daha yetkili bir bölgesel işbirliği girişiminin meydana gelmesi beklenmektedir.

\section{Arktik'te Politikalar ve Çin'in Kutup İpek Yolu Projesi}

\section{Politikalarm Tarihi ve Genel Çerçevesi}

Arktik'in uluslararası alanın tartışılan bir konu olmasının arkasında çevresel endişeler olduğu kadar ulusal çıkar arayışı da bulunmaktadır. Devletler, devlet-altı gruplar, devletler arası yapılar, uluslararası örgütler ve çok uluslu şirketler (enerji, bilişim, maden, medikal vb.) buradaki politikanın aktörleri olarak öne çıkmaktadırlar. Devletler ise hiç şüphesiz genel uluslararası ilişkilerdeki seyirle paralel olacak şekilde en ciddi ve yönlendirici aktördür. Bu çalışmadaki aktör politikası incelemesi devletler üzerinden yapılmış ve Çin de bir örnek olarak seçilmiştir. Bölgedeki devlet politikaları buzulların ortadan kalkmasıyla ortaya çıkacak olan su ve kara alanları üzerindeki hakimiyet, enerji kaynakları başta olmak üzere doğal kaynaklardan yararlanma, balıkçılık, uluslararası ticareti kolaylaştıracak yeni rotalardan faydalanma ve bilimsel araştırma olanakları elde etme üzerinden şekillenmektedir. Hem bölge ile doğrudan fiziksel bağlantısı olan hem de gelişmelerin ve ilgili paylaşımın dişında kalmak istemeyen devletler Arktik'e yönelik özel politikalar geliştirmektedirler.

İnsanlık için ulaşılmaz olarak kabul edilen Arktik Bölgesinin özellikle buzulların erimesiyle birlikte yararlanılma olanakları ortaya çıktıkça jeopolitik ve jeostratejik rekabetin yeni sahası haline gelmiştir (Vardar Tutan ve Arpalıer, 2020:22). Küresel iklim değişikliğiyle birlikte bölgeden geçiş yapılabilecek gün sayısının artması ve su tabanına ulaşılma zorluğunun azalması giderek yoğunlaşan ilginin temelini oluşturmaktadır. ABD Merkezi İstihbarat Teşkilatı (CIA) tarafından hazırlanan "Global Trends 2030" raporunda (2012, s.66-68) Arktik Bölgesi, Hint Okyanusu, Güney Çin Denizi ve Güney Atlantik 
ile birlikte giderek daha fazla çekişmenin merkezi haline geleceği belirtilmektedir. Bölgenin geleneksel güzergâhlara alternatif bir deniz ticaret yolu olarak kullanılma potansiyeli ekonomi hesaplamalarının içerisinde önemli bir yönü oluşturmaktadır.

Arktik'i politik olarak, Arktik Okyanusuna kıyısına sınırı olan devletler arasındaki çoklu ilişkilerin olduğu özel bir alan olarak da tanımlamak mümkündür. Özellikle dış müdahaleden kaçınmak için kimi Arktik Konseyi üyelerinin bu görüşü benimsemesi doğal olarak görülmektedir. Diğer taraftan Arktik'in çevre, ticaret, bilim gibi çeşitli sebeplerle uluslararası bir niteliğinin olduğu ileri sürülmekte ve uluslararası politikanın güncel konularından biri olduğu belirtilmektedir. Diğer bir bakış açısıyla da Arktik'in kendi iç dinamikleri olan bölgesel bir kompleks olarak düşünülmekte ve bu bağlamda siyasi, ekonomik, askeri (güvenlik), toplumsal anlamda özel nitelikli bir alan olarak görülmektedir. Bu yaklaşımların her biri Arktik' in geleceğini olduğu kadar ilgili paylaşımı ve aktör çeşitliliğini ve bu doğrultudaki davranışları da belirlemektedir.

Arktikteki politikalar bir önceki bölümde de anlatıldığı üzere çeşitli işbirliği girişimleri kapsamında ortak bir anlayış çerçevesinde oluşturulurken, rekabet ve çekişme halinin bölgede oluştuğunu ifade etmek mümkündür. Arktik işbirliği ve ortak anlayış vurgsunun güçlü şekilde yapıldığı ama aynı anda da realpolitik üzerinden çıkar yarışının gözlemelnebildiği bir bölge niteliğindedir. Hem bölge hem de bölge dışı devletlerin ortak hareket, öngörülebilirlik ve toplu kazanç veya çıkar, üstünlük ve göreceli kazanç üzerinden konumlanmaları olasıdır. İşbirliğinin artması düzen, istikrar, işbirliği platformları ve uluslararası hukukun uygulanmasına bağliyken ve tüm insanlığın çıkarına hizmet edebilecekken, uluslararası politikanın doğası gereği rekabet ve çatışma da masadaki diğer önemli seçenek olarak durmaktadır (Seval, 2019: 18-19). Soğuk Savaş süresindeki rekabet ve çatışma ortamı 1990larla beraber uluslararası ilişkilerdeki seyre paralel şekilde Arktik Bölgesi için de işbirliğine dönüşmüştür. Batı ve Doğu olarak ayrılan dünyanın üzerinde tanımlandığı askeri tehditlerin bittiğine yönelik inanç, bölgesel ortaklık girişimlerine olan talebi artırmıştır (Heininen, 2011, s. 31-32). Arktik'teki politikalarının aktörlerden bağımsız şekilde fırsatlar ve sorunlar üzerinden tanımlanması mümkündür. Petrol ve doğalgaz gibi enerji kaynakları, değerli madenler, balıkçılık, bilimsel keşif imkânları, ticaret yolları, toprak kazanma, turizm gibi firsatlar bir yanda, hukuki rejim bağlamında uluslararası 
su (açık deniz), kıta sahanlığı, münhasır ekonomik bölge gibi sınırların belirsizliği, küresel iklim değişikliği ve küresel ısınma üzerinden tanımlanan çevre krizleri, eriyen buzullar ve yükselen su seviyesi nedeniyle yerel halkların yaşamlarının tehlikeye girmesi, bölgedeki kültürel birikimin kaybolması, bölgenin askerileşmesi ve askeri denemelerin yapılmasına açık olması gibi sorunlar ise diğer yanda bulunmaktadır (Keskitalo, 2004; Sorensen, 2013; Young, 2009). Arktik Bölgesi'ndeki politikaların çerçevesi devletler hak iddialarını açık şekilde gündeme getirmeleri üzerinden tanımlanmıştır. $\mathrm{Bu}$ hak iddialarının temelinde sınır çerçevesi ve toprak sahipliği, askeri ve güvenliğe dair endişeler, siyasi kazanım ve ekonomik çıkar söz konusudur. Devlet merkezli bir analiz ile yaklaşılacak olursa buradaki politikalar; birinci çember Arktik Bölgesinde toprağı olanlar, ikinci çember bölgeye komşu olan Arktik Konseyi üyeleri ve üçüncü çember de bölge dişındaki devletlerin yönelimlerinin sonucu oluşmaktadır.

Yakın zamanlara kadar sahipsiz topraklardan ve geçit vermez buzlardan oluşan bölgeyle ilgili giderek daha çok dillendirilen "paylaşım sorunu" gündeme gelmiştir. 1982 tarihinde imzalanan ve 1994'te yürürlüğe giren Birleşmiş Milletler Deniz Hukuku Sözleşmesi (BMDHS); küredeki su alanlarıyla ilgili statünün belirlenmesi ve paylaşım sorunlarının çözülmesi amacını taşımaktadır (Pazarcı, 2008, s. 251-252). Sözleşme deniz alanlarıyla ilgili genel bir çerçeve çizerken devletlerden barışçl şekilde ikili veya toplu görüşmelerle sorunlarını çözmelerini esas almaktadır. Arktik Bölgesi'nin yasal olarak bir sahibi yoktur ve hukuken paylaşılmış bir alan değildir. Arktik Okyanusunda ABD Alaska ile, Danimarka Grönland ile, Kanada, Norveç ve Rusya kıyıdaş devlet olarak Birleşmiş Milletler Deniz Hukuku Sözleşmesinin ilgili 57. ve 76. uyarınca 200 deniz millik münhasır ekonomik bölge ve 200 mil veya uygun şartlar var ise 350 mil arasında kıta sahanlığı haklarına sahiplerdir (BM, 1982). ABD dışındaki diğer devletler 1982 Sözleşmesine tamamen taraftır. Fakat Arktik'te statünün belirlenmesinde ABD diğer Konsey üyelerinin BMDHS bağlamında öne sürdükleri düzenlemelere karşı olmamaktadır (Güçlü Akpınar, 2017, s.90-91). Mevcut durumda BMDHS Arktik'te statünün belirlemede yeterli değildir; paylaşım sorunu tamamen bölge devletlerinin ikili veya çoklu anlaşmalarına bağlıdır. Bölgede hukuksal uzlaşının gerçekleşmemesi de hem bölge devletlerinin aralarındaki ihtilaf konularının artmasına hem de uluslararası aktörlerin müdahalelerine neden olmaktadır (Yllmaz ve Çiftçi, 2013, s.14-15). 
Öncelikle belirtmek gerekmektedir ki Arktik Bölgesi'nin statüsü, paylaşımı ile bir antlaşma mevcut değildir. Bu durum da ciddi bir sorunu beraberinde getirmektedir. Benzer süreci tecrübe etmiş olan Antarktika için 1 Aralık 1959 tarihinde imzalanan Antarktika Antlaşması; bölgenin tüm insanlığın mirası olduğunu belirterek sadece bilimsel, çevresel, turistik gibi barışçıl faaliyetlerin gerçekleşmesini mümkün kılmıştır (Antarktika Antlaşması, 1959). Bu Antlaşmanın ardından ise 1972 yılında Antarktik Ayı Balıkları Koruma Sözleşmesi, 1980 yılında Deniz Canlı Kaynaklarının Korunması Sözleşmesi, 1991 yılında ise Çevre Koruma Protokolü imzalanarak Antarktika Antlaşmalar Sistemi oluşturulmuştur (Altıner Coşkuner, 2018, s.115123). Antarktika'nın mevcut durumu bu iken Arktik'te tarihsel bağlamda söz konusu bölge ile ilgili ilk metin Svalbard Adalarının statüsünün belirlenmesi üzerine olmuştur. 1596 yılında keşfedilen ve uzun bir süre boş toprak (terra nullius) olarak görülen Svalbard ve etrafındaki diğer adaların yönetim olarak Norveç'e bağlanmasını öngören Svalbard Antlaşması 1920 tarihinde imzalanmıştır (Greydehoj, Greydehoj ve Akren, 2012, s. 100-102). 1925 yılında ise Norveç, Spitsbergen Takımadıları olarak anılan bölgede kendi iç hukuku bağlamında mutlak ve tam hak sahibi olduğunu belirtmiştir. Bunun yanı sıra Antlaşmaya taraf olan devletlere ve vatandaşlarına; adalara, ilgili sulara, fiyortlara, limanlara giriş ve adalarda ikamet, denizcilik ve madencilik gibi ticari faaliyetler yapma, balıkçlık ve avlanma gibi haklar eşit olarak verilmiştir (Svalbard Antlaşması, 1920). Bu Antlaşma dışında devletleri bağlayıcı başka bir hukuki metin ve BMDHS'nin nasıl uygulamaya konulacağı konusunda uzlaşı olmaması karasuları, münhasır ekonomik bölge, kıta sahanlığı, iç sular, uluslararası su gibi deniz yetki alanlarının sınırı ile ilgili tartışmalar günümüzde var olmaktadır. Örneğin Güneybatı Geçiti'nin Kanada'nın iç su alanı $\mathrm{m} ı$ yoksa uluslararası bir geçiş güzergahı mı olduğu veya Beaufort Denizi sınır noktalarının nereden geçtiği ABD ve Kanada arasında ciddi bir sorunu oluşturmaktadır. Diğer yönden Hans Adaları da Kanada ve Danimarka arasında bir paylaşım sorunudur (Hund, 2014, s.105-108).

Arktikteki politikaların belirleyicisi ve tetikçilerden birinin de küreselleşme olduğunu ifade etmek gerekmektedir. Arktik Bölgesi'ne yönelik artan ilginin arkasında giderek büyüyen/büyümek zorunda olan ekonomilerin ihtiyaç duyduğu doğal kaynaklar için var olan potansiyel, uluslararası ticaret başta olmak üzere serbest dolaşım vurgusu ve çağımızın bir felaketi olarak ön plana çıkan küresel ısınma etkisi küreselleşme ile ilişkilendirilmektedir 
(Heininen, 2011, s.33-39). Özellikle küresel siyasi iddiası olan ve uluslararası ekonomik bütünleşmenin içerisinde var olan devletlerin Arktik yönelimlerinin daha fazla olduğu görülmektedir.

Birinci çevrede olan ABD, Rusya, Kanada, Danimarka ve Norveç bölge üzerindeki asıl egemenlik hakları iddia eden devletlerdir. Bu devletlerin bir yandan kendi aralarında paylaşım ve kullanım hakkı bağlamında çeşitli sorunları olsa da aynı zamanda dış müdahaleden kaçınmak için ortak hareket etmek zorunda kalmaktadırlar. Örneğin 2008 yılında açıklanan Ilulissat Bildirisi; Arktik Konseyi'nin diğer üyeleri olan İsveç, İzlanda ve Finlandiya'nın katılımı olmadan sadece Arktik Beşlisinin bir toplantısının sonucudur ve Arktik Okyanusunda egemenlik hakkı vurgusu yapılmıştır (Ilulissat Bildirisi, 2008). Hiç şüphesiz bu gelişme Arktik Konseyi'nin diğer üyelerini oldukça rahatsız etmiştir. Diğer taraftan Nordik devletler olarak ifade edilen Norveç, İsveç, İzlanda, Danimarka ve Finlandiya'nın da Rusya, Kanada ve ABD'den bağımsız şekilde istişarelerde bulunmaktadırlar. Arktik Konseyi üyeleri arasındaki görüş farklılıkları, ulusal çıkar temelli tartışmalar, paylaşım sorunları olsa da ortak coğrafyayı paylaşma, siyasi ve ekonomik boyutlardaki düzenli ve yoğun etkileşim, dışsal etki de göz önüne alınarak üçüncü taraflara yönelik birliktelik gibi ayaklar çerçevesinde bölgesel bütünleşme de söz konusudur (Sorensen, 2013, s.158-159).

Arktik Konseyi üyeleri arasında anlaşmazlıkların olması oldukça doğaldır; zira günümüz dünyasındaki siyasi kutuplar olarak sayılabilecek $A B D$, Rusya ve $A B$ tam olarak politikaların merkezinde yer almaktadır. Böylesi bir durumda her ne kadar barış ve istikrarın korunmasına yönelik bir söylem hakim olsa da çekişmenin boyutları giderek artmaktadır. Egemenlik ve paylaşım meselesinin Arktik'in stratejik ve ekonomik değeri ortaya çıktıkça daha büyük sorunları beraberinde getireceği aşikardır. Arktik Okyanusunun kıyıdaş devletleri zaman zaman birbirilerini barışçl amaçların ötesine geçmekle ve bölgede silahlanmakla itham etmektedirler (Spohr v.d., 2013). Rusya'nın, Kanada'nın ve NATO'nun bölgede yaptığı askeri tatbikatlar bu bağlamda oldukça önemlidir. Son olarak Mart 2020'de NATO tarafindan 16.000 askerin katılımiyla düzenlenen "Cold Response to 2020" askeri tatbikatı Norveç'te başlamış; fakat Koronovirüs nedeniyle iptal edilmiştir. Rusya özellikle bu noktada ön plana çıkmaktadır; çünkü Arktik Okyanusuna en uzun sinırı olan ülke olarak egemenlik vurgusu bu devletten gelmektedir. Mart 2020'de açıklanan “Rusya Federasyonu'nun 2035'e Kadar Arktik'teki 
Devlet Politikasının Temel Prensipleri" isimli Başkanlık Kararnamesi; bölgenin stratejik bir enerji üssü olması, Kuzey Deniz Yolu'nun deniz ticareti için faaliyete geçirilmesi ve milli ekonomiye yönelik katma değer sağlanması gibi amaçlar içermektedir. Fakat belgedeki asıl önemli vurgu "egemenliğin sağlanması ve toprak bütünlüğünün korunması" üzerine olmuştur (Klimenko, 2020). Önemli bir ayrıntı olarak belirtmek gerekir ki Arktik Konseyi'nin 2019 yılında toplantısında 23 yıllık tarihinde ilk kez bir toplantıdan ortak imzalı deklarasyon çıkmamıştır. Bu durum Konsey üyeleri arasındaki yaşanan iklim değişikliğinin boyutu konusundaki anlaşmazlığın dişa vurumu olarak görülse de esasında paylaşım ve askeri varlık üzerinden yaşanan kutuplaşmanın önemli bir çıtısı olarak algılanabilmektedir.

Bölge dışı bir aktör olarak Avrupa Birliği de AK'de hem daimi hem de gözlemci statüsünde üyeleri olması ve kuzeyindeki gelişmelerin doğrudan Avrupa Kıtasını ilgilendiriyor olmasını neden göstererek Arktik'te var olmasını meşrulaştırmaktadır. Avrupa Komisyonu ve Yüksek Temsilcilik tarafından resmi olarak açıklanan Arktik Politikası; iklim değişikliği ve Arktik çevresinin korunması, sürdürülebilir kalkınma ve Arktik meselelerinde uluslararası işbirliği olmak üzere üç temele dayandırılmaktadır. Küresel iklim değişikliğiyle en büyük mücadeleyi veren aktör olarak kendini tanımlayan Avrupa Birliği, giderek artan enerji kaynağı gereksinimini ve Sami, Iniut gibi yerli halkların yaşam haklarını da belirterek Arktik'te daha fazla etkin olma amacı gütmektedir (Avrupa Komisyonu ve Yüksek Temsilcilik, 2016, s.4). Avrupa Birliği'nin gözlemci statüsü için başvurusu 2009 ve 2011 yillarında Arktik Konseyi tarafindan ertelendikten sonra 2013 yılında da kabul edilmemiş, fakat toplantılara prensipte gözlemci olarak katılması uygun görülmüştür. Bu durumun arkasında Kanada'nın fok avlama ile ilgili yasal düzenleme nedeniyle açıtan karşıtlığı, Rusya'nın ise bir karşı blok olarak AB'nin bölgede yasal olarak var olmasına yönelik üstü örtük itirazı bulunmaktadır (Hossain, 2015, s. 90-91). Avrupa Birliği ise Arktik araştırmalarına ilgisini sürdürmekte ve 2000li yıllarla beraber ilgili projelere yaklaşı 200 milyon Euro kaynak ayrıldığını ifade etmektedir. Arktik dışı diğer grup olan Asyalı devletlerden Çin 2006, Güney Kore 2008, Japonya 2009, Singapur ise

\footnotetext{
${ }^{1} 5$ Mart 2020 tarihli Kararnamenin Rusça orijinaline şu adresten ulaşmak mümkündür: https://portnews.ru/upload/basefiles/2203 0001202003050019.pdf
} 
2012 yılında gözlemci üyelik başvurusunda bulunmuşlardır. Asyalı devletlerin Arktik ilgisinin arkasında çevresel konularda etkinlik gibi nedenler sayılsa da "Yükselen Asya'nın" ekonomik çıkarları ve bölgedeki enerji kaynaklarından yararlanma amaçları da öne çıkmaktadır. Arktik Konseyi üyelerinin kamuoylarında 2013 yılında beş Asyalı devletin gözlemci üye olması ciddi bir endişe doğururken, Kanada gibi ülkeler de bu durumu olumlu bularak gözlemci devletlerin ekonomik, teknolojik ve bilimsel güçlerini bölgeye getirme potansiyelini vurgulamaktadırlar (Tonami, 2016, s. 6-10). Asyalı devletler özellikle ihracat ve ithalat bağlamında yeni bir güzergâh arayışlarını ve bölgenin deniz tabanı zenginliklerine ilgililerini belirtmektedirler (Solli, Wilson Rowe ve Lindgren, 2013, s. 257-260).

Arktik ile ilgili politikaların yoğunlaştığı en ciddi konu alanını, uluslararası alandaki değerine de binaen petrol ve doğalgaz kaynakları oluşturmaktadır. Bir önceki bölümde de bölgedeki enerji kaynaklarının potansiyeli verildiği üzere, Arktik hem devletlerin hem de uluslararası enerji şirketlerin odak noktası haline gelmiştir. Bu kaynaklar üzerindeki paylaşım da bölgede yeni bir büyük oyun sahası oluşturmaya adaydır. Buzulların erimesiyle birlikte Arktik hidrokarbon kaynaklarla ilgili keşif, arama, çıkarma ve işleme faaliyetleri daha mümkün ve maliyeti katlanılabilir hale gelmiştir. Öyle ki 2000li yıllarla beraber British Petroleum, Royal Dutch Shell, StatoilHydro, ENI, Gazprom gibi özel veya devlet destekli şirketler Yüksek Kuzey olarak isimlendirilen bölgelerde araştırma ve çıkarma lisansları almaya başlamışlardır (Johnston, 2010; Cohen, 2011, s. 9-24).

Arktik'te gündeme gelen en önemli konulardan biri de bölgenin güvenliğinin sağlanmasıyla ilgili tartışmadır. Soğuk Savaş'ın sona ermesiyle birlikte bloklar arası çatışma olasılığının gerçekleştirebileceği bir durum kalmasa da bölgenin jeopolitik değerinin artması güvenlik meselesini ön plana çıkarmaktadır. Arktik Konseyi'nin Ottava Deklarasyonu ile kapsamının güvenlik dışında tutulması NATO'nun güvenlik sağlayıcı rolünün tartışılmasına neden olmaktadır. Fakat Rusya, Finlandiya ve İsveç'in NATO üyesi olmamaları ve üye olmasına rağmen Kanada'nın bölgede NATO varlığına olan aleyhtarlığ bu düşünceyi günümüzde geçersiz kılmaktadır. Bölgede 2011 yılında imzalanan Arktik Arama ve Kurtarma Anlaşması ise güvenlik ve emniyet kapsamında bölge devletleri arasında önemli bir girişimi oluşturmaktadır (Ingimundarson, 2014, s.185-189). 


\section{Çin'in Arktik Politikası ve Kutup İpek Yolu}

\section{Çin ve Arktik}

Asyalı devletlerin Arktik'e olan ilgileri büyüyen siyasi ve ekonomik güçleriyle paralel seyirde artmaktadır. Hindistan, Güney Kore, Japonya, Singapur ve Çin için bölgedeki doğal kaynakların ve ticaret yolunun oldukça ciddi önemi ortaya çıkmaktadır. Öyle ki Arktik'in bölge dışı aktörleri olarak Avrupalı devletler ve Asyalı devletler olarak iki gruptan bahsedilmektedir. Asyalı devletlerin Arktik Konseyi'nde var olma talepleri 2013 yılında gözlemci statüsü edinmeleriyle beraber gerçekleşmiştir. Ingimundarson'a (2014, s. 191) göre Asyalı devletlerin Arktik Konseyi'ne kabul edilmesinin iki sebebi bulunmaktadır. Birinci olarak Asyalı devletlerin reddedilmesinin Konsey'in dış dünya tarafından tanınırlığının sorgulanmasına neden olabilecekti, ikinci olarak da Asyalı devletler gerek araştırma üsleriyle gerek yatırımlarıyla bölgede hâlihazırda var olmaktaydılar. Pek tabii tüm bölge dışı aktörler arasında istikrarlı şekilde büyüyen ekonomisi, küresel ticaretteki lider konumu, yurt dışı yatırımları ve enerji, inşaat, ulaştırma gibi alanlarda faaliyet gösteren devasa bütçelere sahip şirketleriyle Çin ön plana çımaktadır. Çin kendini Arktik'e komşu bir ülke olarak tanımlamakta ve burada meydana gelen ekolojik, ekonomik, siyasi gelişmelerde doğrudan iç dinamiklerinin etkilediğini ifade etmektedir.

Arktik Çin için fiziki olarak geçerli olsa da politik değer olarak uzak bir bölge değildir. Siyaset, ekonomi, askeri, kültür, teknoloji gibi alanlarda uluslararası alanın istikrarlı yükselen ve küresel iddiası olan bir aktör olarak Çin'in Arktik ilgisi uzun zamandır var olan bir gerçektir. Bölgenin ekolojik, jeolojik, sosyolojik ve ekonomik yapısı Çin'in ilgisinin temelini oluşturmaktadır. Çin'in özellikle Soğuk Savaş sonrasında ortaya koyduğu küresel güç olma iddiası ve bu bağlamdaki politikası içerisindeki askeri karşılaşmalardan kaçınma, yumuşak gücünü kullanma, ekonomik yatırım yapma, çok boyutlu ilişkiler üzerinden ikili ve çoklu diplomasi kanalları oluşturma, adım adım ilerleme stratejisi benimseme ve gerektiğinde ulusal gücünü ortaya koyma gibi uygulamalar bulunmaktadır (Friedberg, 2011, s. 9-30). Çin'in Arktik'te de büyük stratejisine uyumlu bir yol izlediğini ifade etmek mümkündür. Çin 1925 yılında Svalbard Antlaşmasını imzalayarak bölgeye yönelik ilk resmi gi- 
rişimini yapmıştır. Soğuk Savaş yıllarında ABD ve Sovyetler Birliği eksenindeki kutuplaşmanın Kutup Bölgesi hakimiyeti için de var olması Çin' in sınırlı bilimsel araştırmalar dışında buradan uzak durmasına neden olmuştur. Fakat 1990'larla beraber Çin de bölgedeki gelişmeleri yakından takip etmeye ve bilimsel çalışmaların bir parçası olmaya başlamıştır (Tonami, 2016, s.19). Güncel olarak Çin'in bölgeye yöneliminin somut adımı, 2013 yılında Arktik Konseyi'ne gözlemci devlet statüsü ile katılmasıyla meydana gelmiştir. Özellikle bu tarihten sonra, Çin'in Arktik politikası daha keskin hatlarla belirlenmeye başlamış ve bölgede isminden daha çok söz edilir olmuştur. Uzundur bölgeye olan ilgisini açık şekilde ifade eden ve Arktik üyeleriyle ikili ilişkiler kuran Çin'in, resmi bir kurum altında resmi statüsü de böylece oluşmuştur. Çin'in 2016-2020 yıllarını kapsayan 13. Ekonomik ve Sosyal Kalkınma Planında (2016, s. 40. Bölüm 3. Kısım) deniz çıkarları, deniz güvenliği, ekonomik gelişim, bilimsel araştırmalar ve küresel açılımlar bağlamında kutup bölgelere yer verilmiştir. Bu bağlamda Arktik ve Antarktik'te yeni kıyı araştırma istasyonlarının kurulması, gelişmiş buzkırıcı gemilerin üretilmesi, kutup bölgelerine yer, deniz ve hava gözlem platformlarının kurulması, uygun teknolojinin ve ekipmanın geliştirilmesi için araştırma faaliyetlerinin gerçekleştirilmesi, kutup çevreleri ve potansiyel kaynakları için bilgi altyapısının oluşturulması gibi hedefler konulmuştur.

Çin'in Arktik politikasının çerçevesini 2018 yılının Ocak ayında "Çin Arktik Politikası" başlığıyla yayımlanan Beyaz Kitap’ta bulmak mümkündür. Önsöz ve Sonuç haricinde dört bölümden oluşan söz konusu belgede Çin'in Arktik'teki faaliyetlerinin ve işbirliğinin temelinde; bölgenin yönetişimi için ilgili ortakların katılımlarını teşvik etmek ve Arktik'te barışın, istikrarın ve sürdürülebilir kalkınmanın sağlanması için uluslararası toplumla çalışmak olduğu vurgulanmıştır. Yine aynı belgede Çin'in Kuzey Kutup Dairesi'ne en yakın devletlerden biri olduğunun altı çizilerek özellikle iklim değişikliği, çevre, bilimsel araştırma, ticaret yolları, doğal kaynak arama ve çıarma, güvenlik ve küresel yönetişim konularda ilgisinin olduğu belirtilmektedir. Beyaz Kitap Çin Arktik politikasının özünü "anlamak, korumak, geliştirmek ve yönetişime katılmak" olarak ifade etmektedir. Bilimsel araştırmalarla Arktik'in çok yönlü incelenmesi ve araştırma kapasitesinin artırılması anlamayı; küresel iklim değişikliğine karşı mücadele etme, benzersiz doğal yaşamını ve çevreyi muhafaza etme, yerel halkın sosyal yaşantısını, kültürel ve tarihsel özelliklerine saygıyla yaklaşma korumayı; teknolojik gelişmelerin bölgeye 
getirilmesi, inavasyonun teşvik edilmesi, doğal kaynakların kullanımının artırılması, ticaret yollarının oluşturulması, altyapının güçlendirilmesi geliştirmeyi; Birleşmiş Milletler Sözleşmesi, BMDHS, iklim değişikliği ve çevre ile ilgili uluslararası hukuksal düzenlemeler, Uluslararası Denizcilik Örgütü'nün kuralları, bölgenin ihtiyaçları, güvenlik tehditleri bağlamında sürdürülebilir ve iyi örgütlenmiş bir yönetim mekanizmasının desteklenmesi ise yönetişime katılma amacının çerçevesini çizmektedir (The State Council Information Office, 2018).

Çin 1996 yılında devlet dışı bir yapı olan Uluslararası Arktik Bilim Komitesine katılmıştır ve 1999'dan beri bölgedeki bilimsel araştırmalarını Xue Long (Kar Ejderhası) isimli buz kırıcı özellikteki gemi ile gerçekleştirmektedir. 2004 yllında ise Çin Svalband'da ilk araştırma istasyonu olan Huanghe'yi (Sarı Nehir) açılmıştır. 2012 yılında Xue Long Arktik rotası izleyerek İzlanda'ya ulaşmıştır. Çin'in Arktik Konseyi'ne üye olmasından birkaç ay sonra ise Yong Sheng isimli bir ticari gemi Çin'den başladığı yolculuğunu Hollanda Roterdam Limanı'nda noktalamıştır (Tilmann, Jian ve Nielsson, 2018, s.347-348). 2017 yılında Xue Long'un yaptığı Kuzeybatı Geçiti seferi Çin'in hem kapasitesini hem de niyetini göstermesi açısından da önemli bir adım olmuştur (Gilmour, 2018, s.19-20). 2018 yılının sonuna gelindiğinde Çin toplamda Arktik Okyanusu'nda 8 bilimsel keşif gezisi gerçekleştirmiş ve 14 yıllık bir araştırma faaliyeti geçmişine sahip olmuştur (The State Council Information Office, 2018). Çin ayrıca, Uluslararası Arktik Bilim Komitesi (IASC) tarafından 1999 yılından beri düzenlenen Arktik Bilim Zirvesi Haftasına (The Arctic Science Summit Week) 2005 yılında ev sahipliği yapmış ve diğer zirvelere de yoğun ilgi göstermiştir. Söz konusu hafta, Arktik ile ilgili bilimsel çalışmalar yapan farklı organizasyonların eşgüdümü ve işbirliği için çeşitli etkinliklere sahne olmaktadır (IASC, 2020). Çin sahip olduğu ekonomik ve teknik gücünü Arktik bölgesindeki bilimsel araştırmalar için yoğun olarak işe koşmaktadır. Bunlar salt keşif ve araştırma temelinde girişimler olarak görüldüğü kadarıyla reel politiğin sahne yüzü olarak da algılanabilmektedir. Zira kimi görüşler bölgedeki bilimsel ve çevresel araştırmalara destek verilmeden Arktik'teki politik kararlarda etkili olunması ve ekonomik paylaşımdan pay elde edilmesinin imkansız olduğunu ifade etmektedirler. Çin de bu bağlamda yumuşak gücünü ikili ve çoklu ilişkilere yansıtarak bölgedeki etkinliğini artırma girişiminde olması da oldukça normaldir (Blun- 
den, 2012, s. 126-127). Çin Okyanus kıyıdaşı devletlerin BMDHS'ye göre sahip olduğu hakları tanımakta, hukuka saygısını ifade etmekte ve Norveç ve Rusya örneklerinde görüldüğü üzere de ikili ilişkiler kurarak bölgede talep edilen ülke olma amacı gütmektedir. Diğer taraftan ise yine BMDHS'ye göre bölge dışı devletlerin yaralanabileceği uluslararası sulardaki ve açık deniz tabanındaki bilimsel araştırma, balıkçılık ve keşif gibi haklarına vurgu yapmaktadır (Xinmin, 2019, s.268-269).

Avrupa ve Kuzey Amerika ile ticaretini kolaylaştırması beklenen kuzey yolları ihracat rekortmeni olan Çin'in bölgeye yönelik çıarlarının temel boyutlarından birini oluşturmaktadır. Çin'in kuzey limanlarının kullanılıp Arktik geçişlerinin izlenmesi yolun neredeyse $\% 40$ oranında azalmasını sağlayacakken, hem ağır bir deniz trafiğine sahne olan Malakka Boğazı üzerindeki yükü hafifletebilecek hem de Aden Körfezi gibi deniz korsanlığı tehlikesinin olduğu bölgelerden kaçınmak için alternatif bir güzergâhtan faydalanılmış olacaktır (Chen, 2012, s.361-362). Esasında Çin'in bu yönelimi yeni bir düşüncenin ürünü değildir. 16. yüzyılda Kuzey Avrupa'dan Çin başta olmak üzere "Doğu" olarak nitelenen bölgeye daha kolay ulaşım için düşünülmüştür. Doğrudan Arktik Okyanusu Geçişi, Kuzeybatı Geçişi ve Kuzeydoğu Geçişi bu rota için önemli üç seçenek olarak ortaya çıkmıştır (Serreze ve Barry, 2005, s.4).

Çin'in enerji ihtiyacının karşılanmasında bölge önemli bir potansiyel olarak öne çıkmaktadır. Hem buradaki kaynak zenginliği hem de ulaşım avantajları hiç şüphesiz Çin'in ilgisini cezbeden bir etkendir. Arktik'in enerji potansiyeli Çin'in devasa boyuta gelen sanayileşme ve kentleşme seviyesi bağlamındaki enerji ihtiyacı için kaynak çeşitliliği sağlayabilecektir (Chen, 2012, s. 362). Çin'in büyük enerji şirketleri (CNPC, Sinopec, CNOOC gibi) hiç şüphesiz ki bu bağlamda bölgede Çin'in etkin olma stratejisinin parçalarını oluşturmaktadır. Dünyanın en büyük enerji kaynağı ithalatçısı olan Çin'in Arktik'te arama, çıkarma, işleme ve taşıma gibi faaliyetler için enerji yatırımı yapması beklenen bir gelişmedir. Halihazırda Çin'in Rusya ile Kuzey Buz Denizinde yaptığı doğalgaz çıarma faaliyeti bunun bir örneğidir.

Genel bir söylemle Çin; BMDHS, Svalbard Antlaşması ve uluslararası hukuktan doğan hak ve özgürlüklerini kullanarak bilimsel araştırma, seyrüsefer, balıkçılık, uzun mesafeli uçuş, denizaltı kabloların ve boru hatların döşenmesi, araştırma ve çıkarma faaliyetleri için açı denizlerde, Arktik Böl- 
gesinde ve Arktik okyanusunda var olmak istediğini belirtmekte, ayrıca Birleşmiş Milletler Güvenlik Konseyi'nin (BMGK) daimi üyesi olarak Arktik'teki barışın ve güvenliğin sağlanmasında doğrudan sorumluluğu olduğunu ifade etmektedir. Ulusal çıkarlarının yanı sıra Çin bölgeye yönelik politika ilkelerini de saygı, işbirliği, kazan-kazan politikası ve sürdürülebilirlik olarak tanımlamaktadır (The State Council Information Office, 2018). Çin Arktik'teki eylemlerini hem devlet eliyle hem de özel sektör girişimiyle gerçekleştirmektedir. Bölge devletleriyle birebir siyasi, ekonomik ve ticari, toplumsal, bilimsel, kültürel bağlar geliştirerek ve Arktik'e doğrudan yatırım yaparak varlığını meşru hale getirme stratejisi izlemektedir.

Özetle ifade etmek de gerekirse Çin her ne kadar uzun yıllardır Arktik vurgusu yapsa ve bilimsel araştırmalara katılsa da yakın zamanlara kadar kapsamlı bir politika çerçevesi içerisinde hareket etmemiştir. Fakat Arktik Konseyi üyeliğine kabul ve bölge devletleriyle olan ikili temasların artmasıyla birlikte Çin'in Arktik politikasının hatları belirginleşmeye ve yoğunlaşmaya başlamıştır. Arktik Bölgesi'nin dişında olan bir aktör olarak Çin giderek hem artan şekilde etkisini hissettirme arayışında hem de bölge ülkelerinin tepkisini çekmemeye çalışmaktadır. Çin günümüze gelen süreçte siyasi, ekonomik, bilimsel, teknolojik, diplomatik ve askeri alanda Arktik'te var olmaya çalışan ve küre genelinde uyguladığı büyük stratejisinin bir parçası olarak bölgeye yönelen bir devlet izlenimi oluşturmaktadır (Chen, 2012, s. 359-360). Devlet yetkililerinin yaptığı tüm açklamalarda "anlama, koruma, işbirliği, saygı ve kazan-kazan” vurguları yapmaları ve sert gücünün imasını yapmaktan kaçınmaları politikanın esasını oluşturmaktadır (Tonami, 2016, s.33-35).

Çin; İzlanda, Norveç, Rusya ve Kanada ile Arktik için süreçleri ve boyutları değişen ikili işbirliği girişimleri yürütürken ABD ile küresel rekabetin de bölgeye yansıması olduğu üzere böylesi bir yakınlaşma durumuna girmemektedir. Bölge devletleri ile herhangi bir çatışmadan kaçınarak egemenlik haklarına saygı temelinde ve "bölgeye yakın ama bölge dışı" bir aktör olduğu kabulüyle birlikte hem ikili ilişkilerinden hem de uluslararası hukuktan doğan haklarını kullanmak istediğini belirtmektedir. Bu bağlamda Çin'in ekonomi, diplomasi ve teknoloji yönleriyle ve devlet destekli ve özel şirketleriyle Arktik'te daha etkili ve Arktik'in geleceğini belirleyen kararların alınmasında söz sahibi olacağını ifade etmek güç değildir. 


\section{Kutup İpek Yolu}

Çin; sermaye, teknoloji, pazar, bilgi ve tecrübe güçlerini Arktik Bölgesinde işe koşma niyetini resmi olarak açılamıştır (The State Council Information Office, 2018). Bu niyetinin en önemli çıtılarından birinin Kutup İpek Yolu projesi oluşturmaktadır. Esasında buz üzerinden yeni bir deniz rotası fikri Rusya tarafından ortaya atılmıştır. Özellikle Kuzey Deniz Rotasının deniz ticaretine kazandırılması ve Arktik bölgesindeki enerji kaynaklarının Güneydoğu Asya'nın büyüyen ekonomilerine ulaştırılması üzerine gelişen bir görüştür. 2017 yılının Kasım ayında Çin Devlet Başkanı Xi Jinping ve Rusya Başbakanı Dmitry Medmedev arasında Kuzey Deniz Rotasının kullanımının geliştirilmesi ve Kutup İpek Yolunun hayata geçirilmesi konusunda anlaşmaya varılmıştır (Tilmann, Jian ve Nielsson, 2018, s. 347-349).

Kutup İpek Yolu projesi; Çin'in İpek Yolu Ekonomik Kuşağı ve 21. Yüzyıl Deniz İpek Yolu projelerini içerisine alan Kuşak ve Yol Projesi/Girişimi kapsamında ele alınabilmektedir. Xi Jinping' in 2013 yılının sonbaharında Kazakistan ve Endonezya ziyaretlerinde resmi olarak, Çin'in katılan devletlere ekonomik ve teknik destek vereceği bir ekonomi kuşağı ve deniz yolu oluşturma girişiminden bahsetmiştir. Kısa süre içerisinde Çin Komünist Partisi genel oturumunda da karar alınarak Kuşak ve Yol Projesi tamamen devlet politikası haline getirilmiştir (Durdular, 2016, s.79-80). Bu girişim Asya, Avrupa ve Afrika'daki paydaş devletlerini birbirine bağlamayı amaçlamaktadır. Çok boyutlu, çok taraflı, çok aşamalı ve yoğun ilişkilerin kurulması üzerine temellenen proje ile güzergâh üzerindeki devletlerin sürdürülebilir ve dengeli kalkınmalarının tesis edilmesi hedeflenmektedir (The States Council, 2015). Şüphesiz bu projenin temel hedefi; söz konusu yollar üzerinde siyasi, ekonomik, kültürel, toplumsal bağların geliştirilmesi ve Çin'in küresel açlımının gerçekleştirilmesidir. Bu bağlamda Yol ve Kuşak Projesinin ortağ1 olan devletlere Çin; ekonomik, teknolojik, bilimsel ve insan kaynağı alanlarında destek vereceğini ifade etmektedir. Pek tabii belirtmek gerekmektedir ki Çin'in birkaç farklı bölgeyi farklı kollarıyla on binlerce kilometrelik ticaret yollarıyla bağlaması ve ilgili yatırımlara siyasi ve ekonomik destek vermesi kimi devletler tarafından kazanç fırsatı olarak görülürken kimileri tarafından da Çin'in nüfuzu yayma ve $\mathrm{ABD}$ ile giriştiği küresel ekonomi mücadelede yeni bir boyuta geçme stratejisi olarak da görülebilmektedir (Kutluay Tutar ve Bahsi Koçer, 2019, s.622). 
Çin Halk Cumhuriyeti Ulusal Kalkınma ve Reform Komisyonu, Dişişleri Bakanlığı ve Ticaret Bakanlığı'nın Devlet Konseyi onayıyla 28 Mart 2015 tarihinde ortaklaşa yayınlandakları "İpek Yolu Ekonomi Kuşağı ile 21. Yüzyıl Deniz İpek Yolunun Ortaklaşa İnşa Edilmesini Teşvik Üzerine Vizyon ve Faaliyetler" isimli belgenin 3. Kısmı olan Çerçevede; "İpek Yolu Ekonomi Kuşağ 1 Çin, Orta Asya, Rusya ve (Baltık) Avrupa'yı bir araya getirmeye; Çin'i Orta Asya ve Batı Asya boyunca Basra Körfezi ve Akdeniz'e ve Güneydoğu Asya, Güney Asya ve Hint Okyanusu ile bağlamaya odaklanmaktadır. 21. Yüzyıl Deniz İpek Yolu'nun asıl güzergahları; bir güzergahta Güney Çin Denizi ile Hint Okyanusu yoluyla Çin kıyısından Avrupa ve diğer bir güzergahta Güney Çin Denizi yoluyla Çin kıyısından Güney Pasifik şeklindedir" ifadesi yer almaktadır (Çin Halk Cumhuriyeti İstanbul Başkonsolosluğu, 2015). Hâlihazırda 68 ülkeyi içerisine alan ve kendine özel bir bütçesi bulunan projenin, geliştirilerek daha çok ortağı içerisine alması beklenmektedir.

Çin'in bir önceki bölümde de bahsedilen resmi Arktik politikasında da belirtildiği üzere Kutup İpek Yolu öncelikli girişimler arasında bulunmaktadır. 2017 yılında Çin Ulusal Kalkınma ve Devlet Okyanus İdarisi tarafından "Kuşak ve Yol Projesi Altında Deniz İşbirliği Vizyonu” isimli belge açılanmıştır. Söz konusu belgede (Xinhua, 2017) Çin'in karadan ve sudan tarihi yolları canlandırma girişimi bağlamında taraflar arasında denizlerin ve okyanusların yararlı şekilde kullanılması, ortak anlayışın ve yönetişimin oluşturulması, ticaretin düzenlenmesi ve ilgili engellerin kaldırılması, okyanus temelli refahın genele yayılması, deniz güvenliğin sağlanması gibi amaçlar ortaya konulmuştur. Çin, Kuzey Deniz Rotasını deniz ticareti için zaman ve maliyet tasarrufu olarak algilamakta, bu yolla Kuzey Avrupa ve Amerika'yla olan ticaretini kolaylaştırmayı ve geleneksel deniz yollarındaki risklerden kaçınmayı hedeflemektedir (Liu, 2019, s. 432-433). Çin'in küresel açılımının ve Yol ve Kuşak bağlamında ortaya koyduğu projenin Arktik bölgesine yansıması olarak Kutup İpek Yolu gündeme gelmiştir.

Yol ve Kuşak Projesi kapsamında Çin'in en önemli ortaklarından olan Rusya, Kuzey Deniz Rotasının da canlandırılması gereken bir ticaret yolu olduğu görüşüne en büyük desteği vermektedir. İki devlet arasında gerçekleşen ikili toplantılar sonucundaki işbirliği ve ekonomik ortaklık vurgusu 2010'lı yılların ortalarından itibaren yüzünü "buz üzerinde ticaret yolu” söylemlerinde göstermiştir. Çin Kuzey Deniz Rotasını test etmek için hem 
buz kırıcı gemilerini hem de yaz aylarında ticari gemilerini göndermiştir. Rusya Arktik'te sahip olduğu geniş kıyı şeridi üzerinden egemenlik iddiasını ortaya koyarak Çin'in bölgedeki yatırımını teşvik etmektedir. Çin ise bu rotayı izleyerek hem ticaret yolu çeşitlendirmesi amacı gütmekte hem de Rusya'nın hak iddia ettiği bölümlerdeki deniz tabanı altındaki potansiyel doğal kaynaklara olan ilgisini belirtmektedir (Alexeeva ve Lassere, 2018; Sorensen ve Klimenko, 2017). Arktik'te Kuşak ve Yol Projesi için Rusya kıyılarından Avrasya'yı baştan başa geçen, Arktik Okyanusu üzerinden olan ve doğrudan Kuzey Amerika'ya yönlenen üç rota ön plana çımaktadır. Pek tabii Rusya ile kurulan yakın ilişkiler ve buzun daha hızlı eridiği bölge olması sebebiyle birinci seçenek daha olası görünmektedir.

2013 yılından itibaren Çinli kargo şirketlerinin gemilerinin Kuzey Yolunu kullanamaya başlamalarının ardından, Çin kılavuz kitaplar hazırlamıştır. Günümüze gelen süreçte Arktik'te yol alan Çinli gemilerin sayısı artmıştır; fakat bu artış mütevazı bir biçimde gerçekleşmiştir. Arktik'in kısa vade içerisinde yoğun bir deniz trafiğine sahne olmayacağı aşikârdır. Bölgedeki rotanın kullanılması için limanlar, seyir haritaları, iletişim sistemleri, acil ihtiyaçlar için buz kırıcı hizmetleri gibi altyapıyla ilgili gerekliliklerin tamamlanması gerekmektedir. Çin bu bağlamda hem bu altyapının oluşturulmasına hem de girişim yapacak devletlere gerekli yardımın sağlanmasına aday olduğunu da belirtmektedir (Liu, 2018, s.57-58).

Çin'deki ilgili tartısmalarda kuzey yolunun izlenmesinin gemilerin yakıt masraflarını düşüreceği, kargo süresinin birkaç hafta azalacağı, özellikle Avrupa ile ticaretin daha da gelişeceği, çeşitli deniz güvenlik sorunlarının azalacağı, bölgedeki altyapının kurulmasında Çinli şirketlerin etkin rol alabileceği gibi konular gündeme gelmektedir (Mariia, 2019, s.98-99). Pek tabii diğer yönden de diğer denizlere oranla gemilerin daha yavaş gidebileceği, iklim koşulları nedeniyle seyrüseferin zaman zaman durabileceği, kıyılara yaklaşmanın ve liman faaliyetlerinin daha zor olabileceği, arama kurtarma çalışmalarının daha güç olabileceği, hakkında pek az şey bilenen bir ekosisteme zarar verilebileceği gibi konular da madalyonun diğer yüzünü oluşturmaktadır (Assef, 2018, s.6-7). Fakat ekonomik kâ rlılık ve bölge siyasetinde var olma Kutup İpek Yolunun hayata geçirilmesini daha olası kılmakta ve bu bağlamda Çin de yatırımcıları projeye davet etmektedir. Rusya ile işler haldeki Yamal Sıvılaştırılmış Doğal Gaz İşletmesi, Payakha Petrol Sahası Pro- 
jesi, Zarubino Limanı Projesi, Arkhangelsk Derin Su Limanı Projesi, Finlandiya ile işler haldeki Arktik İzleme ve Araştırma Merkezi, İzlanda ile işler haldeki Arktik Bilim Gözlemevi gibi projeler Çin'in hem Yol ve Kuşak hem de Kutup İpek Yolu girişimleri kapsamında ele alınmaktadır (Chun, 2020). Bunun yanı sıra Xue Long-2'nin 2019 yılında hizmete girmesi ve nükleer enerji ile çalışan bir buz kırıcı gemi projesi için çağrıya çıkılması bu doğrultuda düşünülmektedir.

Kutup İpek Yolu ile ilgili hesaplanması gereken noktalardan birini sürdürülebilirlik oluşturmaktadır. Küresel iklim değişikliğinin neden olduğu kısa, orta ve uzun vadeli gelişmeler bu rotanın da karlılığını, güvenliğini ve sürekliliğini etkileyebilecektir. Ayrıca bölgeden geçecek olan gemilerin neden olacağ kirliliğin de çevresel bazda düşünülmesi gerekmektedir (Liu, 2018, s. 61-62). Zira bir çevre sorunu nedeniyle firsat açılan bir deniz rotasının yeni çevresel sorunlara neden olması tartışmalara ve karşı çıkışlara neden olabilecektir. Çin bu bağlamda sadece siyasi ve ekonomi ilgi boyutuyla değil farklı bilimsel kuruluşları, turizm şirketleri, kültürel girişimler, medya organları ve blog yazarları, gezginler, fotoğrafçlar, sanatçlar gibi bireyleri ile Arktik bölgesine bir bütün olarak yönelim göstermektedir (Mariia, 2019:101). Kutup İpek Yolu projesi de bu kapsamda kültürlerin ve toplumların yakınlaşması adına bir köprü olarak tanıtılmaktadır.

Çin'in Kutup İpek Yolu girişiminin; ekonomik durum, bölgedeki devletlerin bu girişime bakışı, uluslararası hukuk bağlamında Arktik'teki paylaşım, Rusya ve ABD başta olmak üzere Arktik 5'lisi ile ilişkileri, iklim değişikliği ve dolayısıyla buzulların erime süreci, bölgeye yönlendirilen ticaret güzergahının karlılığı gibi etkenler bağlamında faaliyete geçip geçmeyeceği veya gerekli altyapının hazırlanarak ne zaman kullanışlı hale geleceği ortaya çıkacaktır.

\section{Sonuç ve Değerlendirme}

Küresel iklim değişikliği gezegenin var oluşundan bu yana süre gelen doğal bir süreçtir; fakat özellikle son yüzyıllarda dünya insan faktörünün de etkisiyle normal seyrinden daha hızlı şekilde ısınma ve soğuma eğilimi göstermektedir. Şüphesiz bu etkinin en fazla gözlendiği noktaların başında kutup bölgeleri gelmektedir. Antarktik uzun süredir uluslararası kamuoyunun yakından tanıdığı bir bölgeyi oluştururken, Kuzey Kutup Bölgesini oluşturan 
Arktik tanınırlığı nispeten yenidir. Arktik'teki buzulların erimesi sonucunda ortaya çıkan çevresel felaket dünya için yeterli bir endişe sebebidir. Zira deniz suyu seviyesinin yükselmesi, ekolojik dengenin bozulması ve ortaya çıkacak zararlı gazların atmosfere karışması tüm insanlığı etkileyebilecektir.

Arktik'te bir taraftan çevre endişesi var olurken diğer taraftan da ulusal çıkar meselesi gündeme gelmektedir. Zira buzullarla kaplı ve sert iklimi nedeniyle her türden insan faaliyetini oldukça zor kılan bir bölgenin yeni hali bir takım firsatlar da oluşturabilecektir. Çalışma boyunca da bahsedildiği üzere Arktik yeni ticaret rotalarının, enerji kaynaklarının, madenlerin, bilimsel keşiflerin, canlı kaynak avının, bilimsel keşiflerin, turizmin potansiyelini taşımaktadır. Bu bağlamda Arktik'te egemenlik tartışması ve bölgede etkin olma girişimleri giderek artmaktadır. Şüphesiz ki Arktik Okyanusuna kıyısı olan ABD, Rusya, Norveç, Kanada ve Danimarka kilit konumdadır. Bu devletler her ne kadar çeşitli sorunlar yaşasalar da 5'li paylaşım konusunda diş dünyaya karşı ortak hareket edebilmektedirler. Bunun dışında Arktik 5'lisinin yanı sıra İzlanda, Finlandiya ve İsveç' in de daimi üye olarak var olduğu Arktik Konseyi giderek artan konu alanları, çalışma grupları ve gözlemci üyeleri ile önemli bir mekanizmayı temsil etmektedir.

Arktik'in geleceğini şüphesiz ki Arktik Konseyi'nin daimi sekiz devleti belirleyecektir. Fakat ABD'nin, Rusya'nın, bağımsız adımlarıyla dikkat çeken Norveç'in ve üyeleri üzerindeki etkisiyle $A B^{\prime}$ 'nin ayn potada olduğu bir paylaşım sürecinin ne kadar hızlı şekilde sonuçlanacağı ve barış̧̧l araçların ne ölçüde yeterli olacağı merak konusudur. Çevresel tehditlerle mücadelenin yanı sıra ulusal çıkar arayışı Arktik'in kaderinin çerçevesini çizecektir. Bölge devletleri aralarında işbirliği yaptıkları kadar birbirlerine hak iddialarını kabul ettirmeye de çalışmaktalar. Bu bağlamda bölge dışı devletlerin desteğine de zaman zaman başvurulmaktadır. Hâlihazırda Arktik'teki gelişmelerle yakından ilgilenen ve siyasi, ekonomik, askeri, kültürel, bilimsel kazanç arayışında olan Avrupalı ve Asyalı devletlerin de yönelimleri giderek artmaktadır. Bölgedeki paylaşım ve statü ikili ve çoklu anlaşmalarca çözüme kavuşturulmadan yoğunlukları değişecek olan itilafların gerçekleşmesi şaşırtıcı olmayacaktır. Arktik'in insan yaşamına, bilimsel araştırmalara, ekonomik faaliyetlere daha uygun bir bölge haline gelmesi Antarktik'te olduğu gibi "tüm insanlığın kullanımına açık ortak miras" olarak görülmesini imkansızlaşmaktadır. Böylece de aktörlerin güçleri ve etkinlikleri doğrultusunda paylaşımdan pay alacakları sonucunu çıkarmak mümkündür. 
Çin için ise Arktik bir ilgi alanından öteye geçerek büyük stratejisinin bir parçası haline gelmiştir. 2013 yılında Arktik Konseyi üyeliği ve 2018 yılındaki Beyaz Kitap, bu bağlamda düşünülebilmektedir. Çin'in Arktik için dile getirdiği barışçıl araçların kullanılması, uluslararası hukukun uygulanması, bölge devletlerin egemenlik haklarına saygı, toplu kazanç ve bilimsel çalışmalarda ortaklık gibi söylemler sahip olduğu siyasi, ekonomik, askeri, teknolojik, bilimsel ve diplomatik güç ile birleştiğinde bölgede elini sağlam tutmasını sağlamaktadır. Çin'in nüfuz artırma politikasına yönelik çeşitli itirazlar olsa da bölgedeki devletlerin çoğu Çin'in söylemlerini ve yatırım desteğini olumlu karşılamaktadır. Bölge dışı bir aktör olduğunu ama bölgenin o kadar da dışında olmadığını vurgulayan Çin'in Arktik politikalarının temel belirleyicilerden biri olacağını söylemek yanlış değildir. Özellikle de Rusya ile kurduğu yakın ilişki Arktik'te, $A B D$ ve $A B$ karşısında dengeleyici güçlü bir blok oluşturmaktadır.

Kutup İpek Yolu Projesi Çin'in Arktik'in geleceği için ortaya koyduğu en somut ve en çok ses getiren girişim olarak öne çıkmaktadır. Kuşak ve Yol Projesinin buz rotası ayağını oluşturması beklenen projenin Asya ile Kuzey Avrupa ve Kuzey Amerika arasında geleneksel ticaret yollarının mesafe ve zaman olarak kısaltacağı bellidir. Fakat böyle bir projenin hayata geçirilmesinin buzulların erime hızından Arktik'teki paylaşımın boyutuna kadar pek çok değişkeni bulunmaktadır. Yine de projenin gerçekleştirilebilmesinin Çin'in hem küresel açlımında hem de Arktik'teki etkisinde farklı bir boyut açacağını söylemek zor değildir. Kutup İpek Yolu büyük bir atılım gösteren Asyalı devletlerin hem çıkış hem de rakip coğrafyalara giriş güzergâhı olabilecektir. Çin' in yatırım ve teknolojik gücünün yanı sıra Güney Kore, Singapur, Vietnam gibi bölge devletlerin desteğinin sağlanması, Rusya'nın Arktik'teki hak iddialarının desteklenmesi ve Arktik Bölgesi devletleriyle ikili ilişkilerden kaynaklanan diplomatik bağın sürece yansitılması Kutup İpek Yolunu ulaşılabilir hale getirebilecektir. 


\section{EXTENDED ABSTRACT}

\section{Arctic Region Politics: \\ Actor Policies From Ottawa Declaration To Today And China's Polar Silk Road Project}

Emre Çıtak

Hitit University

The Arctic is the north of the polar regions where Antarctica forms the south. In the majority of human history, the polar regions have been considered to be unsuitable for general human life and economic activities due to climate conditions and transportation problem seven though there is an increasing international interest nowadays. Undoubtedly, it is important to state that melting of the glaciers in these regionhave a significant effect behind this trend as an output of global climate change. Although there is general recognition in the international public regarding Antarctic, the Arctic is a relatively new issue. As the thick ice sheets disappeared, the Arctic has become a point where the eyes are turned with the revealing of both the sea and frozen land area in the region.

In fact, the Arctic region has been in a structure that has hosted human life for centuries and at the same time serves various commercial purposes such as coal business and fishing. However, the presence of people in the region has been limited to a small number of local communities that can adapt to living in this particular environment, and due to the low economic profitability, it has not been an intensive investment area. However, as a result of the effects of global climate change, which is seen as a global disaster, opportunities such as scientific research and discoveries for the Arctic, economic income from live and inanimate sources, military trial and exercise, trade routes, and tourism opportunities have been brought to the agenda. Thus, the Arctic Region soon emerged as a political issue where sharing and sovereignty were discussed. The issue is now multilateral and multi-dimensional.

The states that have border to the Arctic Ocean, referred to as the Arctic Five, are the United States (USA), the Russian Federation (RF), Canada, Norway and Denmark. Besides these states, some of the lands of Sweden, 
Iceland and Finland are located in the Arctic Region. The eight states in question are also members of the Arctic Council (EC). Asian states such as China, South Korea, Singapore and European states such as Germany, France and England are also interested in the region, who do not want to be indifferent to the mobility and sharing in the region. While Arctic creating a new hot spot with different aspects such as political, economic, military, cultural, society and environment fort he international public, the most important problem that comes to the agenda is the actor behaviors that take place through sharing in the region. Both regional states and non-regional states want to be as profitable as possible from the sharing in the Arctic. Such an approach will undoubtedly make some conflicts and compulsory cooperation attempts in the Arctic inevitable. For example, the initiative that attracted the most attention of the international public and the most reaction of the riparian states came out when Russia planted a flag on the base of the Arctic Ocean in 2007 by gooing deeper to 4200 meters. After this event, the discussions on the status of the region started to be made from the higher screen.

The current situation of the Arctic is seen as a transnational problem as it poses an environmental threat. It is expected that environmental change in the region, a possible forced migration movement or conflict that may arise from sharing will have global effects. In addition, the potential of energy resources in the region, the emergence of an alternative sea route and the creation of new conditions for scientific research lead to intense international interest. In this context, the identification of the Arctic as a value and the process of increasing the importance of geostratetic, geopolitical and geoeconomic importance are being experienced.

One of the most intensive and serious policy-making states towards the Arctic is China. As an out-of-region actor, China wants to exist in the politics with a peaceful tendency in the Arctic. The official discourse of China in this context is based on building common goals with the states of the region and the rest of the World for he future of the Arctic. After exploring the political, economic, scientific and military potential in the Arctic, China aims to be effective in the region's policies through its bilateral relations and the observer status it achieved in the Arctic Council by stating its position as a close neighbor to the Arctic Circle. Especially since the post-Cold War period, China has made a multi-faceted orientation to the Arctic and announced the White Paper document in 2018 and outlined its official policy. 
While China expresses its willingness to offer its power and experience in the fields of economy, diplomacy, technology, science and trade for the Arctic, it does not hide its search for national interests. The Polar Silk Road, which has the potential of being part of the Road and Belt Initiative that China shared with the international public in 2013, is based on the addition of the Arctic region to the global trade route. The project, which will shorten the transportation between Asia and Europe and North America in terms of distance and cost, is, on the one hand, supported by the international area, especially by Russia, but, on the other hand, creates an opposition because it is perceived as environmental unfriendly and China's attempt to increase influence.

In this study, it is planned to draw the general framework of the actor policies in the Arctic Region. In this context, it is especially important to examine the structure of the Arctic Council. As an example of a policy orientation, China's Arctic policy and the Arctic Silk Road project will be handled. In the first part of the study, general information about the Arctic Region will be given and then the structure of the Arctic Council, which was established in 1996 by the Ottava Declaration, will be mentioned. In the second part, the principles of the actors' behavior in the Arctic will be covered and the outline of China's Arctic policy will be assessed. It is thought that the study will contribute to the field in terms of analyzing the Arctic Region, which is mostly studied on legal status in our country, in a different frame, drawing the general framework of the actor policies and revealing the orientation of China to the region especially through the Polar Silk Road project.

\section{Kaynakça / References}

Alexeeva, O. ve Lassare, F. (2018). An analysis on Sino-Russian cooperation in Arctic in the BRI era. Advances in Polar Sciences, 29(4), 269-282.

Altıner Coşkuner, S. (2018). Antarktika Kıtasındaki Hukuki Rejim ve Türkiye'nin Kıtadaki Varlığı. Ankara Hacı Bayram Üniversitesi Hukuk Fakültesi Dergisi, 22(3), 113-129.

AMAP (2019). Arctic climate change update 2019: an update to key findings of snow, water, ice and permafrost in the Arctic. Arctic Monitoring and Assessment Programme, Tromso: Narayana Press.

Antarktika Antlaşması (1959). Secretariat of the Antarctic treaty. en son 14.04 .2020 ve 28.04.2020 tarihinde https://www.ats.aq/e/antarctictreaty.html adresinden erişilmiştir. 
Arktik Konseyi (1996). Declaration on the Establishment of the Arctic Council: Joint Communique of the Governments of the Arctic Countries on the Establishment of the Arctic Council, Ottava, Kanada, en son 14.04.2020 tarihinde https://oaarchive.arctic-council.org/bitstream/handle/11374/85/EDOCS-1752-v2-ACMMCA00 Ottawa 1996 Founding Declaration.PDF?sequence=5\&isAllowed $=y$ adresinden erişilmiştir.

Arktik Konseyi (2011). Nuuk Declaration: On the occasion of the Seventh ministerial meeting of the arctic council", Nuuk, Grönland en son 02.04.2020 tarihinde https://oaarchive.arctic-council.org/handle/11374/92 adresinden erişilmiştir.

Arktik Konseyi (2019). Arktik konseyi resmi ă̆ sayfası. en son 14.04.2020 tarihinde https://arctic-council.org/en/ adresinden erişilmiştir.

Assef, N. (2018). China's polar silk road: overview, challenges, and oppurtinities. SSRN Electronic Journal, 1-12.

Avrupa Komisyonu ve Yüksek Temsilcilik (2016). Joint communication to the European Parliament and the Council an integrated European Union policy for the Arctic. Brüksel.

Barents Euro-Arctic Cooperation (BEAC) (2020). En son 13.04.2020 tarihinde https://www.barentscooperation.org/en son erişim: 28.04.2020_adresinden erişilmiştir.

Bekkers, E., Francois, J. ve Rojas-Romagosa, H. (2015). Melting ice caps and the economic impact of opening the northern sea route. CPB Discussion Paper: 307. CPB Netherlands Bureau for Economic Policy Analysis, Amsterdam, 1-46.

Bloom, E. T. (1999). Establishment of the Arctic council. The American Journal of International Law, 93(3), 712-722.

Blunden, M. (2012). Geopolitics of Northern Sea route. International Affairs, 88(1), 115-129.

BM (1982). United Nations Convention on the Law of the Sea. Birleşmiş Milletler, en son 22.04.2020 tarihinde https://www.un.org/depts/los/convention_agreements/texts/unclos/unclos_e.pdf son erişim: 28.04.2020_adresinden erişilmiştir.

Box, J. E. v.d. (2019). Key indicators of Arctic climate change: 1971-2017. Environmental Research Letters, 14, 1-18.

Chen, G. (2012). China's emerging Arctic strategy. The Polar Journal, 2(2), 358-371.

Chun, Z (10.01.2020), "China's Arctic Silk Road", The Marimite Executive, https://www.maritime-executive.com/editorials/china-s-arctic-silk-road son erişim: 28.04.2020 adresinden erişilmiştir. 
CIA (2012). Global trends 2030: alternative worlds, national intelligence council. En son 18.04.2020 tarihinde https://globaltrends2030.files.wordpress.com/2012/11/global-trends-2030-november2012.pdf son erișim: 28.04.2020 adresinden erişilmiştir.

Cohen, A. (2011). Russia in the Arctic: Challanges to U.S. energy and geopolitics in the high north. S. J. Blank (Der.), Russia in the Arctic (ss.1-42), Strategic Studies Institute.

Çin Halk Cumhuriyeti İstanbul Başkonsolosluğu, (2015). İpek yolu ekonomi kuşağı ile 21. yüzyll deniz ipek yolunun ortaklaşa inş̧a edilmesini teşvik üzerine vizyon ve faaliyetler. Çin Halk Cumhuriyeti Ulusal Kalkınma ve Reform Komisyonu, Dışişleri Bakanlığı ve Ticaret Bakanlığı'nın Devlet Konseyi, http://istanbul.china-consulate.org/tur/xwdt/t1258666.htm son erişim: 28.04 .2020 adresinden erişilmiştir.

Durdular, A. (2016). Çin'in kuşak yol projesi ve Türkiye-Çin ilişkilerine etkisi. Avrasya Etüdleri, 49, 77-97.

Friedberg, A. L. (2011). A Contest for Supremacy: China, America, and the Struggle for Mastery in Asia. New York ve Londra: W.W. Norton \&Company.

Gautier, D. L. v.d. (2009). Assessment of undiscovered oil and gas in the Arctic. Science, 324, 1175-1179.

Gilmour, J. G. (2018). Icebreaker operation in the Arctic ocean. Journal of Military and Strategic Studies, 18(3), 16-30.

Graczyk, P. ve Koivurova, T. (2014). A new era in the Arctic council's external relations? broader consequences of the nuuk observer rules for Arctic governance. Polar Record, 50(254), 225-236.

Grydehoj, A.; Greydehoj, A. ve Ackren, M. (2012). The globalization of the Arctic: Negotiating sovereignty and building communities in Svalbard, Norway. Island Studies Journal, 7(1), 99-118.

Güçlü Akpınar, B. (2017), uluslararası hukuk çerçevesinden Arktik güvenliği politikalarının analizi: Rusya ve ABD örneği. Savunma Bilimleri Dergisi, 16(2), 83-118.

Heininen, L. (2005),.Impacts of globalization, and the circumpolar north in world politics. Polar Geography, 29(2), 91-102.

Heininen, L. (2011). The end of the post-cold war in the Arctic. Nordia Geographical Publications, 40(4), 31-42.

Hossain, K. (2015). EU enlargement policy: do the policy responses from the arctic states recognise the EU as a legitimate stakeholder? Arctic Review on Law and Politics, 6(2), 89-110. 
Huettman, F.; Schmid, M. (2014). Climate Change in the Arctic. A. J. Hund (Der.), Antarctica and the Arctic circle: a geographic encyclopedia of the Earth's polar regions içinde (s.189-193). California: ABC-CLIO.

Hund, A. J. (2014). Arctic territorial claims and disputes. A. J. Hund (Der.), Antarctica and the Arctic circle: a geographic encyclopedia of the Earth's polar regions içinde (s.105-107). California: ABC-CLIO,

IASC (2020), The Arctic science summit week. en son 13.04 .2020 tarihinde https://iasc.info/assw/about-assw son erișim: 28.04 .2020 adresinden erişilmiştir.

Ilulissat Bildirisi, (2008). Arctic Ocean Conference. en son 01.04.2020 tarihinde https://arcticportal.org/images/stories/pdf/Ilulissat-declaration.pdf son erișim: 28.04.2020 adresinden erişilmiştir.

Ingimundarson, V. (2014). Managing a contested region: the Arctic council and the politics of Arctic governance. The Polar Journal, 4(1), 183-198.

Johnston, P.F. (2010). Arctic energy resources and global energy security. Journal of Military and Strategic Studies, 12(2), 1-20.

Kankaanpaa, P. ve Young, O. R. (2012). The effectiveness of the Arctic council. Polar Research, 31, 1-14.

Keskitalo, E. C. H. (2004). Negotiating the Arctic: The construction of an international region. New York ve Londra: Routledge.

Klimenko, E. (2020). Russia's New arctic policy document signals continuity rather than change. Stockholm International Peace Research Institute, en son 12.04.2020 tarihinde https://sipri.org/commentary/essay/2020/russiasnew-arctic-policy-document-signals-continuity-rather-change son erișim: 28.04.2020 adresinden erişilmiştir.

Kutluay Tutar, F. ve Bahsi Koçer, F. Ş. (2019). Çin'in yeni ipek yolu projesi: Bir kuşak bir yol. International Journal of Social, Humanities and Administrative Sciences, 5(17), 618-626.

Liu, N. (2018). Will China build a green belt and road in Arctic? RECIEL, 27, 55-62. Liu, N. (2019). China's Arctic policy and belt and road initiative: synergy or conflict. The Yearbook of Polar Law Online, 10(1), 431-434.

Mariia, K. (2019). China's Arctic policy: present and future. The Polar Journal, 9(1), 94-112.

NASA (2020). Arctic Sea Ice Minumum. en son 15.04.2020 tarihinde https://climate.nasa.gov/vital-signs/arctic-sea-ice/ son erișim: 28.04 .2020 adresinden erişilmiştir. 
Northern Dimension (2020). en son 15.04.2020 tarihinde http://www.northerndimension.info/northern-dimension son erişim: 28.04.2020 adresinden erişilmiştir.

Nuttall, M. (Der.). (2004). Encyclopedia of the Arctic: vol I. New York ve Londra: Routledge.

Overland, J. (2019). The urgency of Arctic change. Polar Science, 21, 6-13.

Pazarcı, H. (2008). Uluslararası Hukuk. Ankara: Turhan Kitapevi.

Serreze, M. C. ve Barry, R. G. (2005). The Arctic climate system. Cambridge: Cambridge University Press.

Seval, H. F. (2019). Arktik bölge'de uluslararası siyasi düzen: teorik bir yaklaşım. Akdeniz İ̈BF Dergisi, 19 (Özel Sayı), 1-24.

Solli, P. E.; Wilson Rowe, E. ve Lidgren, W. Y. (2013). Coming into the cold: Asia's Arctic interests. Polar Geography, 36 (4), 253-270.

Sorensen, A. T. (2013). From international governance to region building in the Arctic. New Global Studies, 7(2),155-182.

Sorensen, C.T.N. ve Klimenko, E. (2017). Emerging Chinese-Russian cooperation in the Arctic. SIPRI Policy Paper, 46.

Spohr, A. P. v.d. (2013). The militarization of the Arctic: political, economic and climate challenges. UFRGS Model United Nations Journal, 1,11-70.

Svalbard Antlaşması (1920). Treaty between Norway, The United States of America, Denmark, France, Italy, Japan, the Netherlands, Great Britain and Ireland and the British overseas Dominions and Sweden concerning Spitsbergen signed in Paris 9th February 1920 (Antlaşma Orijinal İsmi). en son 20.04.2020 tarihinde http://library.arcticportal.org/1909/1/The Svalbard Treaty 9ssFy.pdf son erişim: 28.04.2020 adresinden erişilmiştir.

TDK, (15.03.2020). Güncel Türkçe sözlük. Türk Dil Kurumu Sözlükleri resmi ağ sayfası en son 20.04.2020 tarihinde https://sozluk.gov.tr/ son erișim: 28.04.2020 adresinden erişilmiştir.

Teterka, B. (2014). Climate change and permafrost. A. J. Hund (Der.), Antarctica and the Arctic circle: A geographic encyclopedia of the Earth's polar regions (s. 187189). California: ABC-CLIO.

Central Committee of the Communist Party of China(t.y). The 13th Five-Year plan for economic and social development of the people's republic of China: 2016-2020, Çev. Compilation and Translation Bureau, en son 20.04.2020 tarihinde https://en.ndrc.gov.cn/policyrelease 8233/201612/P020191101482242850325.pdf son erisim: 28.04.2020 adresinden erişilmiştir. 
The State Council Information Office of the People Republic of China, (2018), China Arctic policy. White Paper, en son 20.04.2020 tarihinde http://english.www.gov.cn/archive/white paper/2018/01/26/content 281476026660336.htm adresinden erişilmiştir.

The State Council of the People Republic of China (2015). Action Plan on the Belt and Road Initiative. en son 20.04.2020 tarihinde http://english.www.gov.cn/archive/publications/2015/03/30/content 281475080249035.htm son erişim: 28.04.2020 adresinden erişilmiştir.

Tillman, H.; Jian, Y. ve Nielsson, E. T. (2018). The polar silk road: China's new frontier of international cooperation. China Quarterly of International Strategic Studies, 4(3), 345-362.

Tonami, A. (2016). Asian foreign policy in a changing arctic: the diplomacy of economy and science at new frontiers. Londra: Palgrave Macmillan.

USGS [United States Geological Survey] (2008). Circum-Arctic resource appraisal: estimates of undiscovered oil and gas north of the Arctic circle", 1-4, en son 20.04.2020 tarihinde https://pubs.usgs.gov/fs/2008/3049/fs2008-3049.pdf son erişim: 28.04.2020 adresinden erişilmiştir.

Vardar Tutan, E. ve Arpalıer, S. (2020). Uluslararası ilişkilerde yeni rekabet alanı olarak Arktik. Barış Araştırmaları ve Çözümleri Dergisi, 8 (1), 21-59.

Xinhua, (2017), "Vision for Maritime cooperation under the belt and road initiative", en son 20.04.2020 tarihinde http://www.xinhuanet.com/english/2017-06/20/c 136380414.htm adresinden erişilmiştir.

Xinmin, M.A. (2019). China's Artic policy on the basis of international law: identification, goals, principles and positions. Marine Policy, 100, 265-279

Yılmaz, N. ve Çiftçi, A. (2013). Arktika bölgesi'nin siyasal önemi ve siyasal ve hukuksal statüsünün karşılaştırmalı değerlendirilmesi. Muğgla Sıtkı Koçman Üniversitesi Sosyal Bilimler Enstitüsü Dergisi, 31, 1-16.

Young, O. R. (2009). The Arctic in play: Governance in a time of rapid change. The International Journal of Marine and Coastal Law, 24, 423-442.

\section{Kaynakça Bilgisi / Citation Information}

Çıtak, E. (2020). Arktik Bölgesi siyaseti: Ottava Deklarasyonu'ndan bugüne aktör politikaları ve Çin'in Kutup İpek Yolu projesi. OPUSUluslararası Toplum Araştırmaları Dergisi, 15(10. Yıl Özel Sayısı), 5438-5473. DOI: 10.26466/opus.733484 